\title{
Membrane-Bound Class III Peroxidases: Unexpected Enzymes with Exciting Functions
}

\author{
Sabine Lüthje ${ }^{1, *}$ and Teresa Martinez-Cortes ${ }^{2}$ (i) \\ 1 Oxidative Stress and Plant Proteomics Group, Institute for Plant Science and Microbiology, \\ University of Hamburg, Ohnhorststrasse 18, 22609 Hamburg, Germany \\ 2 Dpto de Biología Animal, Biología Vegetal y Ecología (Lab. Fisiología Vegetal), \\ Facultad de Ciencias-Universidade da Coruña, A Zapateira s/n, 15071 A Coruña, Spain; \\ teresa.mcortes@udc.es \\ * Correspondence: sabine.luethje@uni-hamburg.de Tel.: +49-(0)40-42816-340
}

Received: 6 August 2018; Accepted: 17 September 2018; Published: 21 September 2018

\begin{abstract}
Class III peroxidases are heme-containing proteins of the secretory pathway with a high redundance and versatile functions. Many soluble peroxidases have been characterized in great detail, whereas only a few studies exist on membrane-bound isoenzymes. Membrane localization of class III peroxidases has been demonstrated for tonoplast, plasma membrane and detergent resistant membrane fractions of different plant species. In silico analysis revealed transmembrane domains for about half of the class III peroxidases that are encoded by the maize (Zea mays) genome. Similar results have been found for other species like thale-cress (Arabidopsis thaliana), barrel medic (Medicago truncatula) and rice (Oryza sativa). Besides this, soluble peroxidases interact with tonoplast and plasma membranes by protein-protein interaction. The topology, spatiotemporal organization, molecular and biological functions of membrane-bound class III peroxidases are discussed. Besides a function in membrane protection and/or membrane repair, additional functions have been supported by experimental data and phylogenetics.
\end{abstract}

Keywords: Arabidopsis thaliana; Class III peroxidase; Medicago truncatula; microdomains; phylogenetics; plasma membrane; protein-protein interaction; Oryza sativa; tonoplast; Zea mays

\section{Introduction}

Classical secretory plant peroxidases (EC 1.11.1.7; class III peroxidases; donor: $\mathrm{H}_{2} \mathrm{O}_{2}$ oxidoreductases) are heme-containing enzymes that belong to the peroxidase-catalase superfamily [1,2]. According to PeroxiBase, as at August 2018 [3], at least 158 class III peroxidases have been identified in the maize (Zea mays L.) genome, 155 isoenzymes in the rice (Oryza sativa L.) genome, 103 isoenzymes in the barrel medic (Medicago truncatula GAERTN. (Gärtner, Joseph)) genome, and 75 isoenzymes in the thale-cress (Arabidopsis thaliana (L.) HEYNH (Heynhold, Gustav)) genome. Differences result partially from some unique peroxidase clusters in monocotyledonous plants that were not found in dicotyledonous plants [4]. Additional isoenzymes can be produced by post-transcriptional and post-translational modifications of peroxidase transcripts $[5,6]$.

As high as the number of peroxidases in plant cells is, so are their implications in different functions various [7-9]: peroxidases are involved in cell wall modifications like lignification, suberisation, and cross-linking of hydroxyprolin-rich glycoproteins and polysaccharides. They are involved in phytohormone metabolism, senescence, and in several biosynthetic pathways, and fulfill important functions in stress-related processes [8,10-12]. Since peroxidases exhibit an almost 1000-fold higher affinity for hydrogen peroxide as catalases and their activities can be modified in the presence of different stress factors, these enzymes play a key role in the detoxification of reactive oxygen species (ROS) [13]. 


\section{Membrane-Bound Class III Peroxidases}

Evidence for membrane-bound class III peroxidases has been presented for different plant species and tissues on the protein level [14]. Guaiacol peroxidase activities have been detected at thylakoid and peroxisomal membranes, tonoplast and plasma membranes [15-20]. Class III peroxidases from tonoplast and plasma membrane (PM) have been partially purified and characterized in more detail [20-22]. Further membrane-bound peroxidases have been identified by genomic and proteomic approaches, but still lack biochemical characterization.

A membrane-bound class III peroxidase has been identified in tonoplast of Madagascar periwinkle (Catharantus roseus (L.) D.DON) leaves [23]. Green fluorescence protein (GFP)-fusion constructs verified localization of CroPrx01 (CrPrx1) at the inner surface of the tonoplast [21].

At the same time, class III peroxidases have been identified in highly enriched PM preparations of maize roots. At least four PM-bound peroxidases (ZmPrx01, ZmPrx66, ZmPrx70 and pmPOX2a) have been partially purified and characterized [22,24]. Depending on the state of development and oxidative stress, further peroxidases have been identified in PM of maize roots [25].

Proteomic and genomic approaches identified PM-bound class III peroxidases in different plant species and tissues; OsPrx95 has been identified in root PM of a salt sensitive rice cultivar [26]. PsPrx13 has been identified in PM of iron deficient pea (Pisum sativum L.) roots [27]. AtPrx64 has been shown to interact with Casparian strip formation at the PM [28,29]. AtPrx64 showed high sequence similarity to AtPrx66 as did AtPrx47 [30]. It was shown that AtPrx66 and AtPrx47 were associated with lignification of vessels, whereas AtPrx64 was associated with lignification of sclerenchyma [30,31]. A recent study demonstrated that aluminum tolerance of tobacco (Nicotiana tabacum L.) plants was improved by overexpression of atprx64 [32].

A localization of class III peroxidases in detergent resistant membranes (DRM) has been demonstrated for PM of barrel medic, maize and sugar beet (Beta vulgaris L.) roots [14,33,34]. MtPrx02 was identified in DRM of barrel medic [33]. A precursor of BvPrx12 has been identified in DRM of sugar beet under iron deficiency [34].

\section{Structure}

The structure of class III peroxidases is well conserved [6]. The proteins contain N-terminal signal peptides, binding-sites for heme and calcium, and four conserved disulfide bridges (Figure 1). Transmembrane domains were predicted for ZmPrx01, OsPrx95, AtPrx47 and MtPrx02, whereas for CroPrx01 and AtPrx64 transmembrane helices (TMH) appear unlikely.

A hypothetical model of CroPrx01 has been published [35]. Besides an $\mathrm{N}$-terminal propeptide (34 amino acids) that directed the GFP-fusion construct of CroPrx01 to the endoplasmic reticulum (ER), a C-terminal extension of 23 to 25 amino acids directed the GFP-fusion constructs of the protein to the vacuole [35]. C-terminal extensions have been found for ZmPrx01 and OsPrx95 (Figure 1). In contrast to CroPrx01, these proteins were identified in highly enriched PM preparations [21,25]. Additionally, prediction of N-glycosylation sites (Table 1) suggested a localization of these enzymes at the apoplastic side.

In accordance with earlier predictions, structures of membrane-bound peroxidases have 13-21 $\alpha$-helices and between two and $11 \beta$-sheets [14,21]. Exceptions were AtPrx47 and AtPrx64, whose hypothetical structures contained no $\beta$-sheets (Figure 2). For AtPrx64, the second calcium binding-site was not conserved (Figure 1). The structures of these peroxidases may need further elucidation.

In comparison to horseradish peroxidase (1HCH1A, HRP) [36], active sites of AtPrx47, AtPrx64, MtPrx02 and ZmPrx01 were well conserved (Figure 1). In contrast, the distal His-42 of HRP was replaced by Val-70 in OsPrx95 (Figure 1). This His facilitates formation of the initial iron-peroxide complex by deprotonating the peroxide and subsequently promote cleavage of the oxygen-oxygen bond by protonating the distal oxygen [37]. In comparison to the wild type HRP, guaiacol peroxidase activity of the H42V mutant was much lower. This observation was in accordance with a 106-fold lower formation of compound I by the mutant in comparison to the wildtype [38]. As a consequence, 
reduction of compound II has been more rapid than reduction of compound I. So far, biochemical characterization of OsPrx95 is lacking.
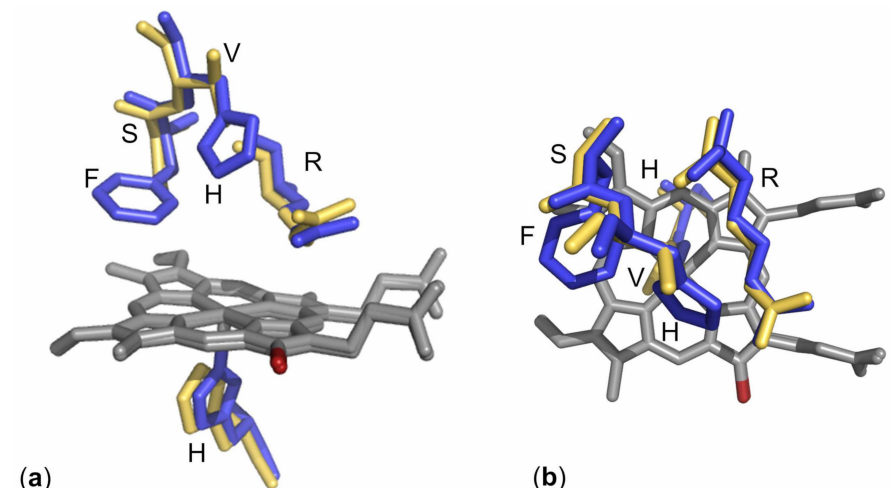

(b)

(c)

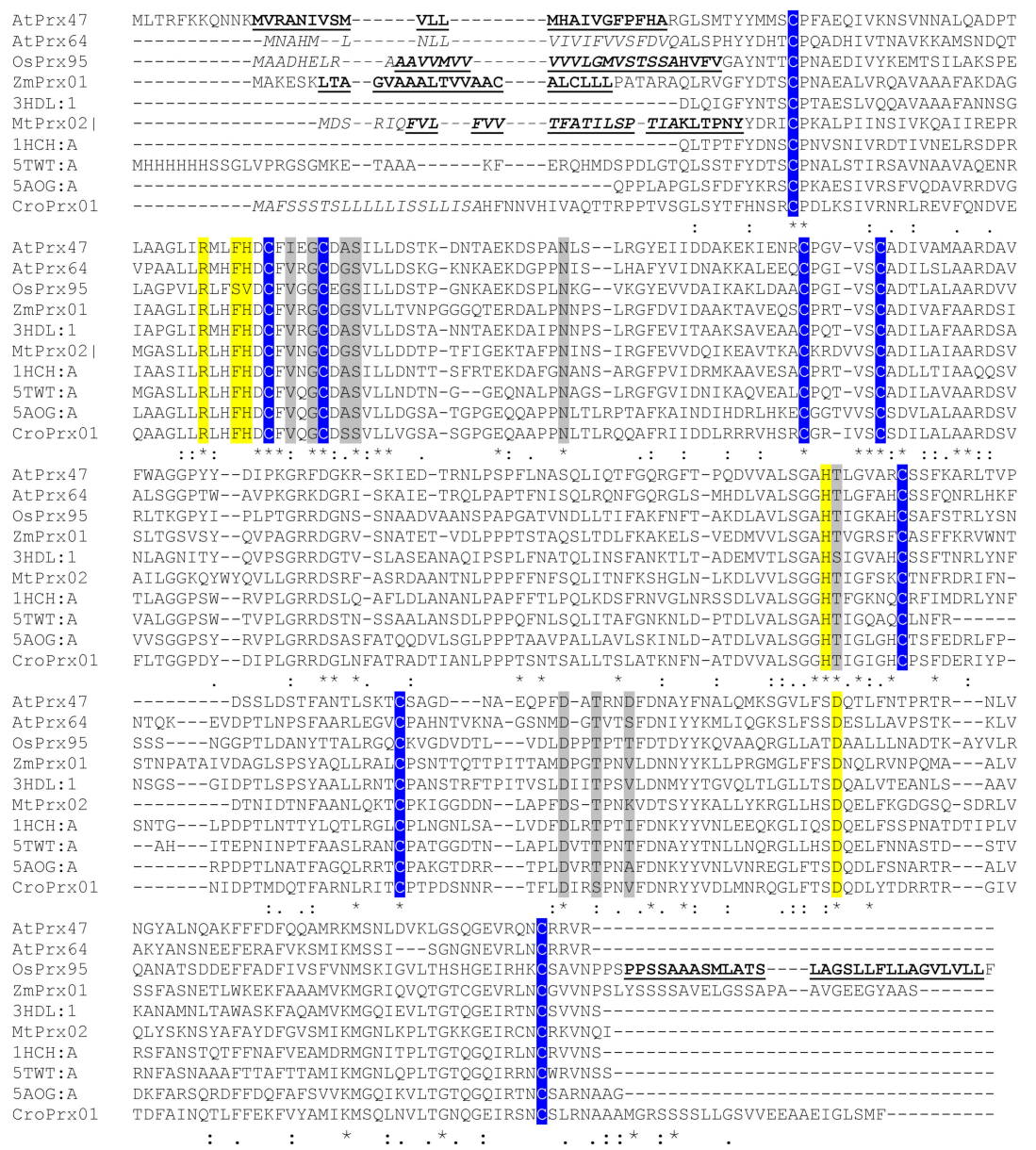

Figure 1. Active sites of horseradish peroxidase (HRP) and OsPrx95 and multiple sequence alignment of class III peroxidases. Superposition of active sites of HRP (blue) and OsPrx95 (yellow) was prepared by Phyton-enhanced molecular graphic tool (PyMOL): (a) site view, (b) top view; in HRP Arg-38 and His-42 build the distal active-site structure [39]. The heme group (grey), with $\delta$-meso edge (red), is fixed by His-170 in the active site. (c) Clustal Omega (https://www.ebi.ac.uk/Tools/msa/clustalo/) was used for multiple sequence alignment of HRP [40], membrane-bound peroxidases and soluble peroxidases that were used as templates for modelling of structures shown in Figure 2 [36,41-43]. Active sites (yellow), calcium binding-sites (grey), conserved cysteine residues for formation of disulfide bridges (blue), transmembrane domains (bold and underlined), signal peptides (italic). 
Table 1. Properties and physiological functions of membrane-bound class III peroxidases of arabidopsis, barrel medic, rice and maize. After identification of peroxidase sequences with trans-membrane domains [44], signal peptides [45], post translational modifications [46] and localisation [47] of proteins have been further analysed by bioinformatic tools. In case of missing experimental data on biological functions these have been predicted by a Basic Local Alignment Search Tool (BLAST) ( $\left.{ }^{*}\right)$ search against all peroxidases (inclusive soluble isoenzymes) with highest sequence similarity and known function. ER, endoplasmatic reticulum membrane; Golgi, golgi apparatus; MoM, mitochondrial outer membrane; MS, identified by mass spectrometry [14]; MW, molecular weight; pI, point isoelectric; PM, plasma membrane; PSORT, protein subcellular localization prediction tool; Vac., vacuole. Predicted pyrrolidone carboxylic acid (PCA) modification (+).

\begin{tabular}{|c|c|c|c|c|c|c|c|c|c|c|}
\hline Species & Acc. No. ${ }^{1}$ & Protein $^{2}$ & $\mathrm{MW}^{3}$ & $\mathrm{pI}^{3}$ & SignalP $^{4}$ & N-Glyco ${ }^{5}$ & NetPhos ${ }^{6}$ & PCA $^{7}$ & PSORT $^{8}$ & Response to \\
\hline \multirow[t]{11}{*}{ A. thaliana } & Q9LE15 & AtPrx04 & 34.28 & 7.87 & $1-19$ & 1 & 39 & + & PM & senescence \\
\hline & Q9FX85 & AtPrx10 & 38.03 & 6.17 & - & 2 & 29 & - & Vac & hormones and stress \\
\hline & O49293 & AtPrx13 & 36.88 & 5.15 & - & 1 & 23 & + & ER & - \\
\hline & Q9SK52 & AtPrx18 & 35.50 & 5.03 & $1-29$ & 2 & 41 & - & PM & floral organ development \\
\hline & O80822 & AtPrx25 & 37.45 & 8.48 & - & 2 & 38 & - & PM & etiolation and drought \\
\hline & Q9SZB9 & AtPrx47 MS & 35.97 & 8.57 & - & 1 & 30 & - & PM & lignification of vessels \\
\hline & O81755 & AtPrx48 & 44.79 & 4.99 & - & 2 & 42 & - & PM & - \\
\hline & P59120 & AtPrx58 & 35.29 & 4.92 & $1-23$ & 2 & 30 & + & PM & - \\
\hline & Q43872 & AtPrx64 MS & 34.71 & 9.05 & $1-22$ & 3 & 30 & - & $\mathrm{PM}$ & etiolation and drought \\
\hline & Q96511 & AtPrx69 & 35.68 & 9.47 & $1-23$ & 3 & 29 & - & ER & etiolation and cold stress \\
\hline & Q9FMI7 & AtPrx70 & 36.00 & 6.97 & $1-23$ & 2 & 25 & - & PM & - \\
\hline \multirow[t]{14}{*}{ M. truncatula } & G7KFK6 & $\mathrm{MtPrx} 02 \mathrm{MS}$ & 36.02 & 9.20 & $1-23$ & 1 & 27 & - & PM & nitrogen starvation, wounding and pathogen \\
\hline & A0A072UYJ4 & MtPrx03 & 35.99 & 5.35 & $1-25$ & 3 & 28 & - & Vac & rhizobium inoculation \\
\hline & G8A179 & MtPrx04 & 35.48 & 8.32 & $1-22$ & 5 & 34 & - & PM & nitrogen starvation and pathogen \\
\hline & A0A072URQ9 & MtPrx09 & 35.92 & 6.51 & $1-25$ & 6 & 41 & + & Golgi & phosphate starvation and pathogen \\
\hline & G7IC23 & MtPrx13 & 35.26 & 8.01 & $1-25$ & 2 & 22 & - & $\mathrm{PM}$ & nodulation and pathogen \\
\hline & G7KFM2 & MtPrx29 & 35.79 & 9.41 & $1-28$ & 1 & 27 & + & PM & drought, wounding, nitrogen starvation, phosphate starvation, \\
\hline & A0A072UJD7 & MtPrx32 & 36.88 & 8.62 & $1-23$ & 1 & 35 & - & PM & $\begin{array}{l}\text { patnogen, mitrogen starvation and pathogen } \\
\text { nirradiation }\end{array}$ \\
\hline & Q1RXM7 & MtPrx34 & 34.38 & 9.11 & $1-22$ & 3 & 32 & - & Vac & drought, insect damage and pathogen \\
\hline & I3S041 & MtPrx37 & 34.90 & 7.15 & $1-22$ & 1 & 30 & - & Vac & drought, insect damage, phosphate starvation and pathogen \\
\hline & G7IF04 & MtPrx39 & 36.19 & 6.5 & $1-25$ & 5 & 31 & - & PM & pathogen \\
\hline & A0A072UQ08 & MtPrx40 & 37.48 & 4.73 & $1-28$ & 2 & 33 & + & PM & pathogen \\
\hline & A0A072TWY1 & MtPrx41 & 34.60 & 5.03 & $1-23$ & 1 & 30 & + & PM & methyl jasmonate, nodulation and pathogen \\
\hline & Q1SC11 & MtPrx42 & 36.08 & 9.09 & $1-25$ & 1 & 27 & + & ER & phosphate starvation and pathogen \\
\hline & A0A072UHR9 & MtPrx49 & 35.30 & 9.72 & $1-25$ & - & 31 & - & Vac & nodulation and pathogen \\
\hline \multirow[t]{14}{*}{ M. truncatula } & G718C1 & MtPrx55 & 34.47 & 9.45 & $1-23$ & 2 & 33 & - & PM & nodulation and pathogen \\
\hline & G7K822 & MtPrx58 & 36.06 & 6.87 & $1-25$ & 2 & 31 & + & ER & nodulation and pathogen \\
\hline & G7JCW8 & MtPrx66 & 34.64 & 8.21 & $1-19$ & 1 & 27 & + & $\mathrm{PM}$ & nitrogen starvation and pathogen \\
\hline & A0A072UYL4 & MtPrx74 & 38.49 & 9.28 & $1-29$ & 2 & 28 & + & PM & nodulation and pathogen \\
\hline & I3T3G6 & MtPrx79 & 36.97 & 8.82 & - & 2 & 48 & - & PM & nodulation* \\
\hline & A0A072UIE4 & MtPrx81 & 35.06 & 8.14 & $1-25$ & - & 30 & - & Vac & pathogen \\
\hline & G7JZ11 & MtPrx83 & 41.78 & 5.78 & $1-23$ & - & 29 & - & $\mathrm{ER}$ & - \\
\hline & G7J9S0 & MtPrx84 & 33.82 & 9.17 & $1-26$ & 2 & 44 & + & PM & - \\
\hline & Q1SAT8 & MtPrx91 & 36.52 & 7.22 & $1-21$ & 3 & 35 & - & Vac & - \\
\hline & G7LB60 & MtPrx92 & 34.76 & 8.81 & $1-25$ & 1 & 40 & - & MoM & nodulation and pathogen \\
\hline & G7JJA7 & MtPrx93 & 35.84 & 5.79 & $1-23$ & 2 & 36 & + & ER & - \\
\hline & G7JKU3 & MtPrx94 & 46.33 & 9.21 & - & 3 & 49 & - & Vac & methyl jasmonate \\
\hline & G7JKV1 & MtPrx95 & 38.06 & 6.14 & - & 5 & 36 & - & PM & methyl jasmonate* \\
\hline & G7J9S2 & MtPrx98 & 33.99 & 8.06 & $1-26$ & 3 & 48 & + & PM & - \\
\hline
\end{tabular}


Table 1. Cont.

\begin{tabular}{|c|c|c|c|c|c|c|c|c|c|c|}
\hline Species & Acc. No. ${ }^{1}$ & Protein $^{2}$ & $\mathrm{MW}^{3}$ & $\mathrm{pI}^{3}$ & SignalP $^{4}$ & N-Glyco ${ }^{5}$ & NetPhos ${ }^{6}$ & PCA $^{7}$ & PSORT $^{8}$ & Response to \\
\hline & G7INU9 & MtPrx[P]113 & 12.74 & 5.56 & $1-24$ & - & 10 & - & ER & cadmium treatment, nodulation, nematode \\
\hline & $\mathrm{A} 2 \mathrm{Q} 4 \mathrm{~B} 7$ & MtPrx[P]116 & 33.77 & 7.98 & $1-14$ & 1 & 23 & - & PM & infection and pathogen * \\
\hline & G7JCW9 & MtPrx[P]117 & 17.60 & 6.23 & $1-19$ & - & 13 & - & PM & nitrogen and phosphate starvation and pathogen * \\
\hline \multirow[t]{18}{*}{ O. sativa } & Q5VR15 & OsPrx01 & 34.78 & 6.88 & $1-24$ & 1 & 30 & - & ER & - \\
\hline & Q5U1T6 & OsPrx07 & 31.93 & 5.32 & $1-20$ & 1 & 27 & - & PM & - \\
\hline & Q5U1T4 & OsPrx09 & 35.50 & 5.67 & $1-11$ & 5 & 31 & - & PM & etiolation and drought* \\
\hline & Q5U1T3 & OsPrx10 & 36.20 & 5.38 & - & 5 & 34 & - & Vac & - \\
\hline & Q5U1T0 & OsPrx13 & 36.18 & 5.16 & $1-21$ & 8 & 18 & - & PM & - \\
\hline & Q6ER51 & OsPrx30 & 34.43 & 7.52 & $1-26$ & 1 & 33 & + & PM & - \\
\hline & Q5U1R1 & OsPrx32 & 34.06 & 8.42 & $1-30$ & 2 & 30 & - & PM & pathogen * \\
\hline & Q5U1Q7 & OsPrx36 & 50.76 & 4.85 & $1-17$ & 2 & 45 & + & Vac & pautuger \\
\hline & Q5U1P7 & OsPrx46 & 35.95 & 7.02 & $1-29$ & 1 & 20 & - & Vac & nitrogen and phosphate starvation * \\
\hline & Q7XUL1 & OsPrx5556 & 51.48 & 9.15 & $1-26$ & 5 & 86 & + & PM & gibberellic acid and heat ${ }^{*}$ \\
\hline & Q6AVZ8 & OsPrx65 & 37.61 & 7.20 & $1-24$ & 2 & 21 & - & MoM & drought* ${ }^{*}$ \\
\hline & Q8L3W2 & OsPrx95 MS & 37.58 & 5.63 & $1-28$ & 6 & 38 & - & PM & - \\
\hline & Q6Z121 & OsPrx100 & 32.78 & 5.68 & $1-20$ & 2 & 27 & - & $\mathrm{PM}$ & - \\
\hline & Q6Z121 & OsPrx101 & 32.78 & 5.68 & $1-20$ & 2 & 27 & - & PM & - \\
\hline & Q8GVG6 & OsPrx106-1 & 40.15 & 7.22 & $1-19$ & 2 & 47 & - & Vac & - \\
\hline & A2YP47 & OsPrx106-2 & 40.15 & 7.22 & $1-19$ & 2 & 45 & - & Vac & - \\
\hline & Q8GVG0 & OsPrx107 & 34.23 & 9.19 & $1-22$ & 3 & 15 & - & ER & nitrogen and phosphate starvation * \\
\hline & Q5U114 & OsPrx109 & 33.02 & 8.26 & $1-21$ & 4 & 32 & + & ER & $\begin{array}{c}\text { anaerobic stress, brassinolide and giberellic acid treatments and } \\
\text { nematode infection * }\end{array}$ \\
\hline \multirow[t]{6}{*}{ O. sativa } & Q6Z3Y8 & OsPrx116 & 36.05 & 7.69 & 1-19 & 1 & 29 & + & MoM & pH and oxidative stress * \\
\hline & Q5U1H6 & OsPrx117 & 33.51 & 6.65 & $1-25$ & 1 & 30 & - & PM & $\mathrm{pH}$, oxidative stress, nitrogen starvation and pathogen * \\
\hline & Q6UU25 & OsPrx118 & 36.93 & 4.96 & $1-25$ & 2 & 23 & - & Vac & Pl \\
\hline & Q7XHB1 & OsPrx126 & 35.48 & 4.45 & $1-27$ & 1 & 33 & + & PM & $\mathrm{pH}$, oxidative stress, nematode infection and pathogen * \\
\hline & Q5U1F8 & OsPrx135 & 34.83 & 8.79 & $1-31$ & 3 & 38 & + & PM & 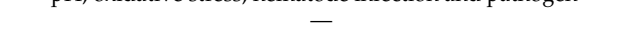 \\
\hline & Q5U1F5 & OsPrx138 & 35.66 & 8.40 & - & 2 & 17 & - & PM & nitrogen starvation * \\
\hline \multirow[t]{25}{*}{ Z. mays } & A5H8G4 & ZmPrx01 MS & 38.36 & 6.81 & - & 5 & 35 & - & PM & cell wall modification, wounding and pathogen \\
\hline & A0A1D6KUF1 & ZmPrx11 & 35.44 & 5.14 & $1-28$ & 3 & 28 & + & PM & $\mathrm{pH}$, oxidative stress and pathogen * \\
\hline & B4FHG3 & ZmPrx24 MS & 37.82 & 5.9 & $1-25$ & 2 & 36 & - & PM & $\begin{array}{l}\mathrm{pH} \text {, oxidative stress, abscissic and ethylene stress, etiolation and } \\
\text { heat shock* }\end{array}$ \\
\hline & B4FD28 & ZmPrx26 & 37.50 & 5.01 & $1-38$ & 3 & 34 & - & MiM & $\mathrm{pH}$, drought and pathogen * \\
\hline & B6T173 & $\mathrm{ZmPrx35}$ & 36.80 & 6.05 & $1-22$ & 2 & 24 & - & ER & 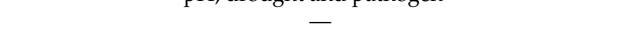 \\
\hline & A0A1D6H655 & $\mathrm{ZmPrx36}$ & 33.09 & 4.90 & $1-24$ & 2 & 29 & + & MoM & heat and oxidative stress * \\
\hline & B4FVT1 & ZmPrx39 & 37.91 & 8.30 & $1-21$ & 8 & 34 & - & MoM & $\begin{array}{l}\text { pathogen } \\
\text { sicss }\end{array}$ \\
\hline & B4FJX1 & ZmPrx41 & 35.75 & 4.88 & - & 1 & 30 & - & PM & $\mathrm{pH}$, drought and etiolation * \\
\hline & A0A1D6FBJ6 6 & ZmPrx46 & 38.65 & 6.19 & $1-23$ & 1 & 33 & - & ER & P- \\
\hline & Q9ZTS6 & ZmPrx52 & 34.59 & 8.96 & $1-27$ & 4 & 29 & - & PM & pathogen * \\
\hline & K7VQBO & ZmPrx53 & 46.55 & 4.98 & $1-24$ & 1 & 42 & + & Vac & - \\
\hline & B6TU39 & ZmPrx55 & 34.96 & 4.85 & $1-42$ & 1 & 33 & + & PM & cold stress \\
\hline & A0A1D6IMZ0 & ZmPrx56 & 34.57 & 4.35 & $1-25$ & 3 & 36 & - & PM & pathogen * \\
\hline & B6T5R9 & ZmPrx57 & 37.58 & 5.73 & $1-19$ & 3 & 26 & - & PM & pathogen * \\
\hline & B4FH68 & ZmPrx58 MS & 36.91 & 6.35 & $1-25$ & 1 & 30 & - & PM & $\begin{array}{l}\mathrm{pH} \text {, oxidative stress, abscissic and ethylene stress, etiolation and } \\
\text { heat shock * }\end{array}$ \\
\hline & A5H454-1 & ZmPrx66 MS & 33.42 & 8.39 & $1-29$ & 4 & 70 & + & PM & $\begin{array}{c}\begin{array}{c}\text { heat shock** } \\
\text { drought }\end{array} \\
.\end{array}$ \\
\hline & A0A1D6H655 & ZmPrx67 & 32.77 & 4.89 & - & 4 & 26 & - & MoM & heat, drought, pathogen and oxidative stress * \\
\hline & A5H452 & $\mathrm{ZmPrx} 70^{\mathrm{MS}}$ & 33.41 & 9.08 & $1-25$ & 4 & 34 & + & $\mathrm{ER} / \mathrm{PM}$ & drought \\
\hline & B4FMF8 & ZmPrx71 & 35.71 & 9.64 & $1-28$ & 3 & 30 & - & PM & - \\
\hline & B4F7T9 & ZmPrx72 & 36.67 & 9.31 & - & 2 & 22 & - & $\mathrm{MiM}$ & nitrogen starvation * \\
\hline & B6SNF9 & ZmPrx76 & 33.30 & 8.64 & $1-24$ & - & 33 & - & ER & $\begin{array}{l}\text { drought } \\
\text { dit }\end{array}$ \\
\hline & B4FH35 & ZmPrx77 & 35.71 & 9.64 & $1-32$ & 6 & 20 & + & ER & - \\
\hline & A0A1D6IKW2 & ZmPrx78 & 41.42 & 5.86 & $1-21$ & 3 & 40 & + & Vac & $\mathrm{pH}$ and drought* \\
\hline & B4FG39 & ZmPrx81 & 36.42 & 7.66 & $1-29$ & 3 & 35 & - & PM & drought \\
\hline & A0A1D6E530 & ZmPrx85 & 35.48 & 5.35 & $1-23$ & 1 & 32 & - & PM & pathogen \\
\hline
\end{tabular}


Table 1. Cont.

\begin{tabular}{|c|c|c|c|c|c|c|c|c|c|c|}
\hline Species & Acc. No. ${ }^{1}$ & Protein $^{2}$ & $\mathrm{MW}^{3}$ & $\mathrm{pI}^{3}$ & SignalP $^{4}$ & N-Glyco ${ }^{5}$ & NetPhos ${ }^{6}$ & PCA $^{7}$ & PSORT $^{8}$ & Response to \\
\hline \multirow[t]{20}{*}{ Z. mays } & Q9ZTS8 & ZmPrx86 & 35.51 & 4.37 & $1-21$ & 3 & 34 & + & PM & pathogen \\
\hline & A0A1D6HQQ9 & ZmPrx89 & 36.08 & 4.87 & $1-32$ & 10 & 23 & + & MiM & $\mathrm{pH}$, anoxia, ethylene and gibberellic acid * \\
\hline & A0A1D6HQQ8 & $\mathrm{ZmPrx} 94$ & 37.24 & 5.82 & $1-29$ & 6 & 30 & - & PM & drought \\
\hline & B6TWB1 & ZmPrx102 & 37.11 & 6.00 & $1-26$ & 4 & 24 & - & Vac & $\mathrm{pH}$ and pathogen * \\
\hline & A0A1D6IKX3 & ZmPrx103 & 57.26 & 5.06 & $1-27$ & 4 & 106 & - & Vac & pritus - \\
\hline & B4FBHO & ZmPrx104 & 38.04 & 8.09 & $1-27$ & 2 & 23 & - & Vac & etiolation * \\
\hline & B4FYH1 & ZmPrx109 & 37.94 & 6.00 & $1-22$ & 3 & 40 & - & $\mathrm{PM}$ & pathogen $*$ \\
\hline & A0A1D6J1L2 & $\mathrm{ZmPrx} 112$ & 41.37 & 7.03 & $1-27$ & 6 & 64 & - & PM & etiolation, drought and pathogen * \\
\hline & A0A1D6KQI0 & ZmPrx113 & 38.28 & 10.26 & - & 3 & 27 & - & PM & \\
\hline & СОРPB6 & ZmPrx114 & 32.71 & 5.20 & $1-23$ & 5 & 38 & + & PM & $\mathrm{pH}$, drought and pathogen $*$ \\
\hline & B6U6W0 & ZmPrx115 & 37.59 & 8.31 & $?$ & 3 & 40 & + & PM & etiolation, cell wall modification, wounding and pathogen * \\
\hline & A0A1D6H652 & ZmPrx122 & 34.37 & 6.88 & $1-28$ & 2 & 29 & + & PM & drought* ${ }^{*}$ \\
\hline & B4FA32 & ZmPrx123 & 34.01 & 6.50 & $1-25$ & 1 & 25 & + & PM & etiolation, abscisic acid and pathogen * \\
\hline & A0A1D6N9N5 & ZmPrx124 & 37.42 & 4.84 & $1-23$ & 2 & 25 & - & $\mathrm{PM}$ & $\mathrm{pH}$ and sulfur deficiency * \\
\hline & K7TMB0 & ZmPrx128 & 35.80 & 8.05 & $1-36$ & 3 & 30 & - & MoM & - \\
\hline & K7U151 & ZmPrx129 & 33.75 & 6.80 & $1-26$ & 1 & 20 & - & PM & - \\
\hline & A0A1D6JNY2 & ZmPrx132 & 46.64 & 4.99 & $1-22$ & 1 & 40 & + & Vac & - \\
\hline & K7VFH6 & ZmPrx135 & 35.67 & 4.98 & $1-31$ & - & 22 & - & ER & abscisic acid and heat * \\
\hline & C4IZ20 & ZmPrx136 & 34.48 & 8.45 & $1-22$ & 2 & 21 & - & PM & etiolation, drought and pathogen * \\
\hline & A0A1D6JF04 & ZmPrx140 & 37.88 & 8.88 & $1-21$ & 3 & 31 & - & PM & $\mathrm{pH}^{*}$ \\
\hline
\end{tabular}

${ }^{1}$ http://www.uniprot.org $/ ;^{2}$ http://peroxibase.toulouse.inra.fr $/ ;^{3}$ https://web.expasy.org/protparam $/ ;^{4}$ http://www.cbs.dtu.dk/services/SignalP/; ${ }^{5}$ http:// www.cbs.dtu.dk/ services/NetNGlyc/; ${ }^{6}$ http://www.cbs.dtu.dk/services/NetPhos $/ ;^{7}$ https://prosite.expasy.org/; ${ }^{8}$ http://psort1.hgc.jp/form.html. 
In silico analyzes of putative membrane-bound peroxidases revealed at least one glycosylation-site with the exception of some endoplasmatic reticulum (ER) and vacuolar peroxidases (Table 1). These membrane-bound peroxidases were predicted to be highly phosphorylated. Glycosylation of class III peroxidases seem to be necessary for protein folding, stability and catalytic activity [48]. Glycosylation is necessary for activity of PM-bound peroxidases [22]. Phosphorylation may change properties of the enzymes and be involved in protein-protein interaction. These predictions have to be verified by experimental data.

(a)

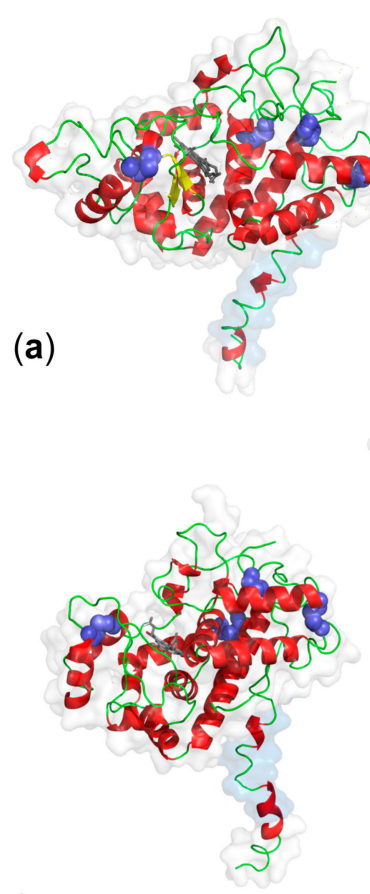

(d)

Figure 2. Putative tertiary structures of PM-bound class III peroxidases. Structures were predicted by SWISS-MODEL for (a) ZmPrx01 (3hdlA, 1 TMH, root PM), (b) OsPrx95 (3hdl1A, 3 TMH, root PM), (c) AtPrx64 (3hdl1A, 0 TMH, PM), (d) AtPrx47 (5twt, 1 TMH, PM), and (e) MtPrx02 (5twt1A, 1 TMH, root tip DRM). N-terminal amino acid sequences containing transmembrane domains (marine) were modeled by ab initio with Phyre2 in intensive mode [49]. Ligand binding-sites were predicted by 3DLigandSite [50]. The hypothetical models were prepared by PyMOL (http://pymol.org/) and present the structural characteristics of class III peroxidases. Colors indicate secondary structures: $\alpha$-helix (red), $\beta$-sheets (yellow), loops (green), disulfides (blue), and haem group (grey).

\section{Topology and Spatiotemporal Organization}

All class III peroxidases appear to have a cleavable signal peptide in common. In silico analyzes of 142 class III peroxidase sequences from maize predicted putative signal peptides, transmembrane domains and the localization of these proteins. This approach revealed a ratio of $53 \%$ soluble to $47 \%$ membrane-bound isoenzymes [14]. Among the membrane proteins, signals for localization at the endoplasmatic reticulum (ER, 42\%), PM (55\%), Golgi ( $2 \%$ ) and tonoplast (1\%) were predicted.

A comparison between rice, barrel medic, arabidopsis and maize showed similar results about the number of isoenzymes with putative transmembrane helices, $51 \%$ in rice $(n=78), 49 \%$ in maize $(n=77)$, $35 \%$ in barrel medic $(n=36)$ and $44 \%$ in arabidopsis $(n=33)$. The protein subcellular localization prediction tool (PSORT) indicated a PM localization for at least eight class III peroxidases in arabidopsis, 17 in barrel medic, 13 in rice and 27 in maize (Table 1). Additionally, peroxidases were predicted for ER, Golgi, mitochondria outer (MoM) and inner (MiM) membranes. A vacuolar localization was predicted for seven peroxidases in rice and barrel medic, for six in maize, and for one in arabidopsis. A possible 
localization of these vacuolar peroxidases at the tonoplast will need further proof. For maize roots, peroxidases have been detected at the tonoplast [51].

The properties of PM-bound peroxidases from maize and the identification of class III peroxidases in DRM suggested a tight interaction with the membrane [14,22,24,33,34]. According to membrane-bound ascorbate peroxidases that interact with the membrane via a C-terminal membrane-spanning segment [16,52-59], PM-bound class III peroxidases appeared to be anchored by an uncleavable $\mathrm{N}$-terminal signal peptide with a transmembrane helix. Beyond that, proteomic approaches suggest protein-protein interaction [60].

\subsection{Transmembrane Spanning Domains}

In general, N-terminal signal peptides are cleaved off during maturation of soluble secretory peroxidases from eukaryotic organisms. In many cases, the resulting $\mathrm{N}$-terminal positioned glutamine is catalyzed to a cyclic molecule, the so-called pyrrolidone carboxylic acid (PCA) [61]. Prosite predicted such a modification for 32\% of the peroxidases shown in Table 1 [62]. Four (OsPrx36, ZmPrx53, ZmPrx78, ZmPrx132) out of 21 vacuolar peroxidases are modified this way potentially. Pyrrolidone carboxylic acid appear absent in CroPrx01 [21] and vacuolar peroxidases from arabidopsis and barrel medic. One third of the putative PM-bound peroxidases showed an N-terminal glutamine that may be modified after cleavage of the signal peptide [21].

Three transmembrane helices (TMH) were predicted for OsPrx95 by different prediction tools [14]. PSORT identified a cleavable signal peptide at the N-terminus of OsPrx95 and predicted a type I membrane protein (TMH 345...361, C-terminus) with a localization at the PM (Table 1). This prediction was in accordance with the identification of the protein in the PM [26]. In contrast, the hypothetical model showed a transmembrane domain at the N-terminus (Figure 2). All other peroxidases from Table 1 have one TMH at the N-terminus that is overlapping with the ER signal peptide. Signal peptides of membrane-bound proteins can remain and, due to their hydrophobicity, function as an N-terminal transmembrane domain. Actual search algorithms may be not able to make exact predictions of this possibility yet. So far, crystal structures of membrane-bound peroxidases have not been published.

In accordance with the biochemical classification and with the identification of ZmPrx01, ZmPrx66, and $\mathrm{ZmPrx} 70$ at the PM, five of $n=5$ prediction programs detected $\mathrm{N}$-terminal signal peptides in their amino acid sequences [22]. PSORT even predicted a non-cleavable signal peptide in ZmPrx70 and a localization of the enzyme at the PM or ER membrane (Table 1). The hypothesis of a transmembrane-spanning domain was supported by experimental data: (i) non of the maize peroxidases could be washed off from the PM by high salt concentrations or other treatments [22,24,63]; (ii) peroxidases were found in DRM of washed PM [14]; (iii) recombinant peroxidases were localized in the yeast membrane after heterologous expression of their full length amino acid sequences [64].

\subsection{Protein-Protein Interaction}

Molecular masses of ZmPrx01 (70 kDa) and pmPOX2a (155 kDa) suggested a putative protein-protein interaction [22,24]. Analyzes of the maize PM proteome by high resolution clear native electrophoresis (hrCNE) pointed to the participation of a PM-bound guaiacol peroxidase to a putative high molecular mass protein complex of $1092 \mathrm{kDa}$ [60]. Interaction of AtPrx64 with PM-bound Casparian strip domain proteins (CASPs) was demonstrated [28]. For tonoplast, interaction of CroPrx01 with arabinogalactan proteins (AGPs) was suggested [35].

Protein-protein interaction may be supported by post-translational modifications (Table 1). Phosphorylation may change the properties of peroxidases and facilitate protein-protein interaction, although this hypothesis has to be verified.

\subsection{Spatiotemporal Organization}

The proteome of PM microdomains (defined by DRM) is involved in signaling and response to biotic and abiotic stress, cellular trafficking, cell wall synthesis and degradation, and metabolism $[65,66]$. 
Evidence for a localization of class III peroxidases in DRM has been presented [14,33,34]. As shown in Figure 3, microcompartimentation allows PM-bound peroxidases to co-localize with ROS producing and detoxifying enzymes in the membrane [25]. Thus PM-bound peroxidases may probably not only detoxify $\mathrm{H}_{2} \mathrm{O}_{2}$ directly at the site of origin to ensure the optimal protection of the membrane, but could also protect specific functional regions of the PM $[14,25]$ and fulfill specific functions in dependence on their substrates.

AVLB biosynthesis

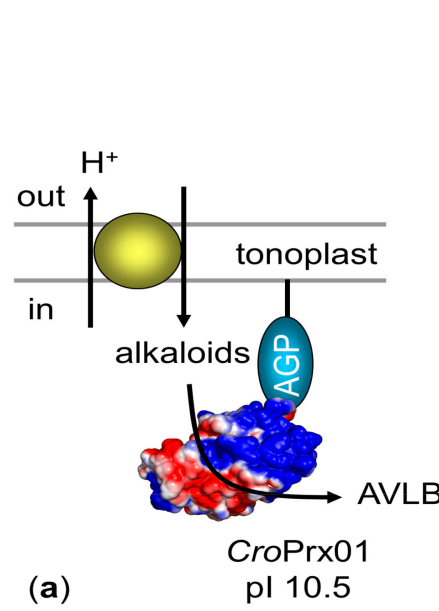

Cell wall modification Casparian strip formation

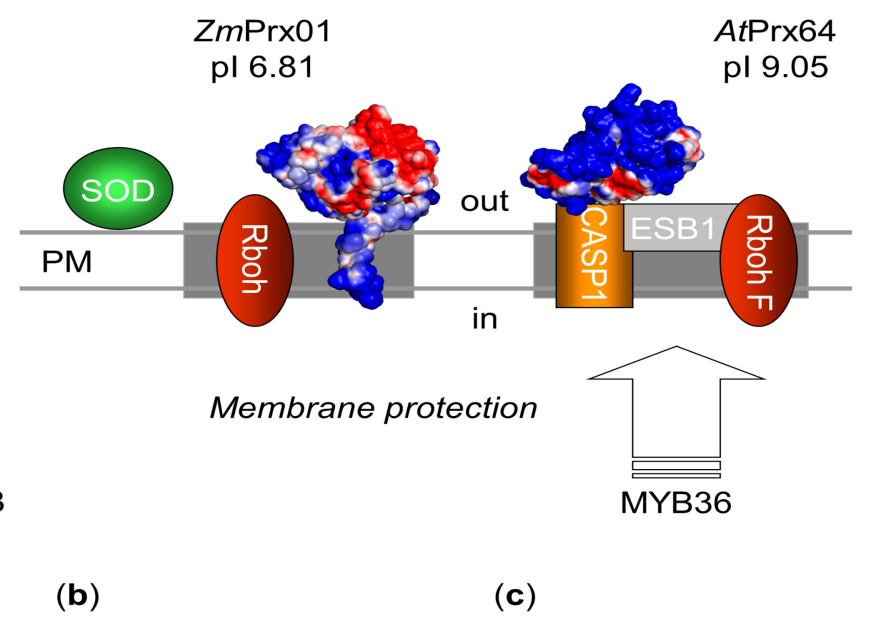

Figure 3. Membrane interaction and spatiotemporal organization of CroPrx01, ZmPrx01 and AtPrx64. (a) Soluble CroPrx01 interacts via an arabinogalactan protein (AGP, blue) with the inner surface of the tonoplast $[35,67]$. For $\alpha-3^{\prime}, 4^{\prime}$-anhydrovinblastine (AVLB) synthesis, the complex anchored next to a proton driven alkaloid antiporter (yellow ellipse) [68,69], (b) ZmPrx01 is anchored in the PM by a transmembrane-spanning domain with its active site at the out-side [22]. For cell wall modification, the enzyme co-localized with Rboh (ruby colored) in microdomains. Simultaneously, superoxide dismutase (SOD, green) and ZmPrx01 regulate ROS levels at the PM [14,70]. (c) Soluble AtPrx64 interact with a transmembrane Casparian strip protein (CASP1, orange) at the PM [28,29,71,72]. A dirigent-like protein (EBS1, grey) facilitates co-localization of the complex with RbohF (ruby colored) in sclerenchyma cells [72]. Casparian strip formation is regulated by MYB36 [29]. For peroxidases solvent accessible surface charges are shown: negative (red); neutral (white), positive (blue).

A co-localization of AtPrx64 with respiratory burst oxidase homolog $\mathrm{F}$ (RbohF) has been shown [28]. Besides AtPrx64, RbohF, and a dirigent-like protein (Enhanced Suberin 1, ESB1) were recruited by CASPs to assemble the lignin polymerization machinery [29]. It was shown that this process is regulated by the transcription factor MYB36.

The pattern of CroPrx01:GFP-fusion constructs pointed to localization in mircodomains. A co-localization with AGPs was postulated at the tonoplast [35]. Regulation of CroPrx01 functions were discussed in dependence on the specific localization/orientation.

\section{Function}

Functional analysis and biochemical characterization of membrane-bound class III peroxidases are still fragmentary. It is very difficult to identify the exact function(s) of plant peroxidases because of (i) the huge amount of similar isoenzymes, (ii) the broad substrate specificity, (iii) the high number of possible functions, and (iv) the ability of other isoenzymes to compensate the absence of an enzyme in knock-out experiments [11,73]. Progress has been made by molecular biological approaches in combination with biochemical characterization that resolve some of these problems [74]. 


\subsection{Molecular Function}

Class III peroxidases are involved in production and scavenging of ROS $[7,8,75]$. Various substrates are oxidized by the peroxidative cycle that play important functions in polymerization of cell wall components, auxin metabolism, and $\mathrm{NAD}(\mathrm{P}) \mathrm{H}$ oxidation via a non-catalytic reaction. Superoxide anion production via this reaction is immediately converted to hydrogen peroxide and molecular oxygen either spontaneously or through superoxide dismutase. The hydroxylic cycle can produce ROS. Both cycles control hydrogen peroxide levels of cells [25]. A function of hydrogen peroxide in redox regulation and signaling has been demonstrated [76,77].

\section{Substrates}

The PM is the first target of a stressor. Large amounts of hydrogen peroxide are produced at the PM due to cellular processes, as a response to stress factors, or to external sources in plant-pathogen interactions [78-81]. This oxidative stress causes lipid peroxidation and changes in membrane permeability [82-84]. PM-bound peroxidases were suggested to be substantially involved in the detoxification of the cell and/or repair of the PM after oxidative damage [25]. They probably play an important role in maintaining the cell functions under different stress conditions [22].

Class III peroxidases oxidize a wide variety of small phenolic compounds, including monolignols, hydoxycinnamic acids, dimeric alkaloids and others $[85,86]$. For the docking study shown in Table 2, several of these substrates were tested: (i) monolignols such as coniferyl, sinapyl, and $p$-coumaryl alcohols as precursors of lignin [87,88]; (ii) hydoxycinnamic acids like ferulic acid, caffeic acid and $p$-coumaric acid as precursors of suberin [89]; (iii) L-3,4-dihydroxyphenylalanine (L-DOPA) as precursor of various alkaloids, catecholamines, and melanin [90,91]; and (iv) other substrates like ascorbic acid, indol-3-acetic acid (IAA) and nicotinamide adenine dinucleotides (NAD(P)H). Auxins like IAA have a crucial role in the cell elongation process [92] and can be accumulated in vacuoles [93].

The docking analysis revealed different substrate affinities for the peroxidases in dependence on their localization and biological function. According to their classification, the peroxidases showed low affinity against ascorbic acid (Table 2).

PM-bound peroxidases of arabidopsis, barrel medic or rice (Figure 1), have not been characterized biochemically yet. For AtPrx64, the substrate affinity decreased in the order NADPH $>$ IAA > NADH $>$ L-DOPA > cinnamyl alcohol > sinapyl alcohol > ferulic acid (Table 2). Gene expression of AtPrx64 indicates that this peroxidase is crucial to lignin deposition in the Casparian strip of endodermis cell walls in roots $[28,29]$. This observation correlates with affinities of the hypothetical structure of the enzyme against alcohols such as cinnamyl and sinapyl (Table 2).

The affinity of AtPrx47 decreased from NADPH $>$ IAA $>$ NADH $>$ ferulic acid $>$ cinnamyl alcohol. The docking analyzes revealed that L-DOPA appears not to be a substrate for AtPrx47. These results supported a function of AtPrx47 in the lignification of vessels [30].

PM-bound MtPrx02 showed a high affinity for substrates related to cell wall modification, such as IAA, ferulic acid, cinnamyl and sinapyl alcohol (Table 2). This observation confirmed experimental data with this peroxidase [94]. Similar results were found for OsPrx95 that showed high affinity with substrates involved in cell wall modification such as IAA and cinnamyl alcohol (Table 2).

Both, CroPrx01 and AtPrx64, revealed similar affinities with L-DOPA, whereas the other peroxidases showed no reaction with this substrate. This observation excluded a localization of AtPrx47, MtPrx02, OsPrx95 or ZmPrx01 at the tonoplast or in the vacuole. As mentioned above, the structure of AtPrx64 may need further elucidation and results from the docking study have to be verified by biochemical characterization of the native enzyme and/or recombinant polypeptide. Biochemical differences between native proteins and recombinant polypeptides may be possible due to a distinct degree of glycosylation. 
Table 2. Docking results of multiple ligand molecules by Firedock (http://bioinfo3d.cs.tau.ac.il/ FireDock/). Putative structures of the membrane-bound peroxidases CroPrx01 (5aog.1.A), AtPrx64 (3hdl.1.A), AtPrx47 (5twt.1.A), MtPrx02 (5twt.1.A), OsPrx95 (3hdl.1A) and ZmPrx01 (3hdl.1.A) were modeled by SWISS-MODEL (https:/ / swissmodel.expasy.org/). Horseradish peroxidase (HRP, 1hch) was used for comparison.

\begin{tabular}{cccccccc}
\hline Substrate & CroPrx01 & AtPrx64 & AtPrx47 & MtPrx02 & OsPrx95 & ZmPrx01 & HRP \\
\hline ascorbic acid & -5.47 & -5.39 & -5.94 & -5.48 & -5.56 & -5.29 & -5.88 \\
L-DOPA $^{1}$ & -8.23 & -8.39 & 0.24 & 12.62 & 7.11 & 12.34 & -0.34 \\
indole acetic acid & -15.41 & -13.66 & -12.95 & -17.24 & -13.05 & -13.6 & -11.79 \\
NADH $^{2}$ & -9.26 & -8.6 & -12.82 & -12.42 & -13.32 & -9.89 & -6.29 \\
NADPH $^{3}$ & -12.93 & -13.69 & -13.78 & -11.69 & -11.95 & -12.49 & -5.44 \\
cinnamyl alcohol $^{\text {coniferyl alcohol }}$ & -7.95 & -7.98 & -7.67 & -8.74 & -7.67 & -6.39 & -5.85 \\
sinalpyl alcohol & -7.56 & -4.33 & -3.77 & -3.73 & -4.85 & -4.54 & -3.81 \\
ferulic acid & -6.8 & -7.88 & -5.23 & -8.02 & -6.51 & -7.26 & -3.35 \\
caffeic acid & -5.35 & -5.34 & -8.14 & -9.04 & -6.11 & -5.22 & -6.86 \\
p-coumaric acid & -4.96 & -5.77 & -5.32 & -5.98 & -5.91 & -4.88 & -2.07 \\
\hline${ }^{1}$ DOPA, L-3,4-Dihydroxyphenylalanin; ${ }^{2} \mathrm{NADH}$, Nicotinamide adenine dinucleotide; ${ }^{3}$ NADPH, Nicotinamide \\
adenine dinucleotide phosphate.
\end{tabular}

Cinnamyl alcohol is easily oxidized by most of the peroxidases, but coniferyl and sinapyl alcohol seem to be poor substrates for many of these enzymes. Thus even during lignin synthesis, sinapyl alcohol dehydrogenation may be mediated by other phenolic radicals $[95,96]$.

\subsection{Biological Functions}

The expression of peroxidase enzymes is regulated and induced by several stressors, such as pathogens, temperature, nutrient starvation or environmental changes [74]. Regulation of peroxidases is strongly effected by ROS levels in the plants. These ROS levels are linkups to the stressors, related besides the self-regulation of the plant [97].

Although class III peroxidases are highly conserved, the high similarity in protein structure has no simple correlation with the functions of these enzymes. Nevertheless, the structural features of class III peroxidases, like distribution of surface charges, glycosylation patterns or even the regulation of the enzymes, seem to be important in the classification by functions of the enzymes [74]. Another feature that was used to characterize peroxidases is the isoelectric point (pI) [6]. So far, little or no information can be found on the correlation between $\mathrm{pI}$ and biological functions.

Both, alkaline and acidic stress, generate an increase of ROS in plant tissues [98-100]. Those changes in soil $\mathrm{pH}$ and apoplast have a significant effect on the regulation of peroxidases that are linked to ROS generation and scavenging. On the one hand, several studies showed optima in the range between $\mathrm{pH} 4.5$ to 6.5 for peroxidase activity [101,102]. On the other hand, $\mathrm{pH}$ is crucial for the stability of peroxidases [103].

Evaluation of Table 1 revealed several membrane peroxidases that respond to $\mathrm{pH}$ in rice $(n=2)$ and maize $(n=11)$, but none in arabidopsis or barrel medic. In maize, a localization of these isoenzymes was predicted for PM $(n=7)$, vacuole $(n=2)$ and mitochondria inner membrane $(n=2)$. In rice, two isoenzymes were predicted for PM. All these peroxidases were anionic with the exception of ZmPrx140 (Table 1).

A proteomic approach suggested specific functions of ZmPrx01, ZmPrx66, ZmPrx70 and pmPOX2a in response to oxidative stress [63]. Both, substrate affinity and specific activities make a function of $\mathrm{ZmPrx} 01$ in lignification most likely. Several putative cis-regulatory elements were identified by partial gene analysis of ZmPrx70 that suggested a regulation of its gene by wounding, methyl jasmonate, salicylic acid, and elicitors [22]. In addition, a regulation of the gene by oxidative stress was suggested by seven successive elements with sequence similarity to the consensus sequence of antioxidant-responsive elements (ARE) at the 5'-untranslated region of ZmPrx70 [63,104]. 
Recent studies showed that high-light conditions can increase phenol and peroxidase levels and by that the hydrogen peroxide scavenging capacity of the vacuole. In fact it was proposed that the vacuolar couple CroPrx01/secondary metabolites represent an important sink/buffer of hydrogen peroxide in green plant cells [105].

\subsubsection{Orthologous}

According to Welinder et al. [61], truly orthologous of peroxidases should have sequence identities greater than $90 \%$. For the peroxidases discussed above, orthologous were not found for the species investigated. Sequence similarities above $70 \%$ might indicate related physicochemical properties and physiological functions.

Homologous of AtPrx47 appear not to exist in arabidopsis, highest sequence similarity was $47 \%$ (Table 3). For AtPrx47, a function in lignification of vessels has been shown during plant development $[29,30]$. This observation was supported by the docking analyzes (Table 2). Several proteins with sequence similarities above $80 \%$ to AtPrx 47 were found in the Brassicaceae family, e.g., AruPrx47 (94.9\%) from horseradish (Armoracia rusticana G.GAERTN., B.MEY (Bernhard. Meyer). and SCHERB. (Scherbius, Johannes)). Sequence similarities above $70 \%$ were indicated for MtPrx19 (G7IJT4) and CroPrx09. However, MtPrx19 was suggested to have a function in response to pathogens, whereas the function of CroPrx09 is unkown. For maize and rice, sequence similarities were below $60 \%$. In contrast to AtPrx47, none of the putative orthologous appear to have a transmembrane-spanning domain or a localization at the PM.

Table 3. Homologous and most similar sequences of membrane-bound class III peroxidases in other species. Sequence identity is given in brackets. Protein names are given according to PeroxiBase.

\begin{tabular}{|c|c|c|c|c|c|}
\hline Protein & Z. mays & O. sativa & M. truncatula & A. thaliana & C. roserus \\
\hline CroPrx01 & ZmPrx16 (55\%) & OsPrx23 (53\%) & MtPrx48 (54\%) & $\operatorname{AtPrx12}(59 \%)$ & CroPrx03 (84\%) \\
\hline AtPrx 64 & ZmPrx136 (65\%) & OsPrx32 (60\%) & MtPrx55 (72\%) & AtPrx66(52\%) & $\begin{array}{l}\text { CroPrx40 }(72 \%) \\
\text { CroPrx43 }(72 \%)\end{array}$ \\
\hline AtPrx 47 & ZmPrx15 (57\%) & OsPrx117 (60\%) & MtPrx19 (71\%) & $\begin{array}{l}\text { AtPrx66 (47\%) } \\
\text { AtPrx64 (46\%) }\end{array}$ & CroPrx09 (75\%) \\
\hline MtPrx02 & ZmPrx120 (52\%) & OsPrx40 (59\%) & $\operatorname{MtPrx} 70(96 \%)$ & AtPrx52 (46\%) & CroPrx04 (55\%) \\
\hline OsPrx95 & ZmPrx94 (73\%) & $\begin{array}{l}\text { OsPrx97 (50\%) } \\
\text { OsPrx134 (50\%) }\end{array}$ & MtPrx07 (43\%) & $\operatorname{AtPrx} 56(46 \%)$ & $\begin{array}{l}\text { CroPrx49 (48\%) } \\
\text { CroPrx59 (47\%) }\end{array}$ \\
\hline ZmPrx1 & ZmPrx101 (68\%) & OsPrx12 (74\%) & $\operatorname{MtPrx} 07(52 \%)$ & $\operatorname{AtPrx39}(46 \%)$ & CroPrx14 (48\%) \\
\hline
\end{tabular}

Similar results have been found for the tonoplast-bound CroPrx01. Sequence similarity of $84 \%$ was found between CroPrx01 and CroPrx03 (B2G335), but in maize, rice, barrel-medic or arabidopsis, sequence similarities were below $60 \%$. CroPrx03 is a soluble apoplastic peroxidase that is expressed in stem and flower tissues [106]. The transcript was down-regulated under salt and dehydration stress.

For the barrel medic MtPrx02, MtPrx70 (G7KFK8) was found as homologous by sequence similarity (Table 3). Indeed this peroxidase responded to nitrogen starvation and pathogen infection. In contrast to MtPrx02, MtPrx70 respond to mycorrhiza and appears to be a soluble peroxidase. PSORT predicted localization outside the cell and the enzyme does not contain a transmembrane helix. Arabidopsis, rice and maize showed similarities below $60 \%$ (Table 3).

True orthologous of OsPrx95 were not indicated in maize, barrel medic or arabidopsis. Highest sequence similarity to OsPrx95 was found for ZmPrx94 (A0A1D6HQQ8). Both proteins were predicted at the PM (Table 1). Salt stress caused a decrease in OsPrx95 abundance [27]. In contrast, ZmPrx94 was induced by salinity. The lignin biosynthesis pathway altered significantly under salt stress. For example, cell wall thickness of vessels in sorghum [107] and thickness of Casparian strip in maize roots [108] increased during acclimation to salinity.

Orthologous of ZmPrx01 were not found in rice, Madagascar periwinkle, barrel medic or arabidopsis. In maize, ZmPx101 (B4FU88) and ZmPrx49 (B4FY83) showed highest sequence similarity 
to ZmPrx01. Both proteins appear to be soluble peroxidases. ZmPrx101 is induced by pathogens, whereas the function of ZmPrx49 is unknown.

Similar results were found by comparison of all ER, PM and vacuolar peroxidases from arabidopsis, barrel medic, rice and maize. Among ER-bound peroxidases, the highest sequence identity was between ZmPrx135 and MtPrx58 (47.33\%), the lowest between ZmPrx46 and AtPrx69 $(37.15 \%)$. In total, 45 putative PM-bound peroxidases were found. The highest sequence identities were found for ZmPrx41 and ZmPrx55 (97.95\%) > ZmPrx66 and ZmPrx114 (80.89\%) > OsPrx135 and ZmPrx115 (80.43\%) > OsPrx30 and ZmPrx123 (79.88\%), but for most of them sequence identities were below $60 \%$.

ZmPrx41 responded to $\mathrm{pH}$, drought and etiolation, whereas ZmPrx55 appears to have a function in cold stress. ZmPrx66 showed response to drought, ZmPrx114 appears to have a function in drought stress, but responded also to pathogens and $\mathrm{pH}$ (Table 1). ZmPrx115 was affected by etiolation, and is involved in cell wall modification whereas the function of OsPrx135 is unkown.

For vacuolar peroxidases sequence identities were below $60 \%$ with the exception of $\mathrm{ZmPrx} 53$ and ZmPrx132 (86.28\%). Functions of these peroxidases are unknown.

\subsubsection{Phylogeny}

A phylogenetic tree was performed to obtain further clues to the biological functions of membrane-bound peroxidases in maize, rice, barrel medic and arabidopsis (Figure 4). The phylogenetic tree was constructed using the maximum likelihood method based on the Jones, Taylor, Thornton (JTT) matrix-based model [99]. The analysis was done with amino acid sequences of peroxidases from Table 1. In total 110 sequences were analyzed, Eleven from arabidopsis, 31 from barrel medic, 22 from rice, 45 from maize and one from the liverwort Marchantia polymorpha (MpPrx92). The tree was rooted to MpPrx92. The amino acid sequence reveals no signal peptide, it has a prediction for $1 \mathrm{TMH}$ and for a localization of the protein at the PM. Phylogenetic analysis allows identifying the evolutionary conservation and divergence of these enzymes from the common ancestor MpPrx92.

The tree was divided into six major groups (A to F). The first group, which clusters peroxidases that respond to various stresses, is subdivided in four clusters (A1 to A4). Cluster A1 summarized peroxidases that were characterized to work against several stresses, like drought (e.g., MtPrx29, ZmPrx66 and ZmPrx70), cold (ZmPrx55), pathogens (e.g., MtPrx02, MtPrx32 and ZmPrx86) and even hormones (e.g., AtPrx10 and MtPrx94). Cluster A2 contains only two PM peroxidases that participate in oxidative stress (OsPrx117) and lignification of vessels (AtPrx47). In fact the similarity between the two peroxidases is remarkable (Table 3), but the similarities of biological functions need further proofs. In group A3, peroxidases clustered together that are involved in reactions against pathogens (e.g., AtPrx64, MtPrx55 and MtPrx92) and nodulation (e.g., MtPrx13, MtPrx55 and MtPrx92). Nodulation is characteristic for legumes like barrel medic [109]. Peroxidases from other species in this cluster work most probably in defense against pathogens. Finally, the cluster A4 is formed exclusively by PM peroxidases of maize that are involved against stresses like drought (ZmPrx81) and defense against pathogens (ZmPrx85).

Group B is subdivided into two clusters but there is not so much known about this group.

Group $C$ is subdivided in five clusters with different responses to abiotic stress. Group C1 contains peroxidases that were not characterized experimentally. A BLAST search suggests a function in response to $\mathrm{pH}$ changes, such as soil acidification. This group is formed only by maize peroxidases, with the exception of OsPrx95 from rice. Maize and rice are two of the bigger crops in the world, and frequently the growing of these plants is related to soil conditions. Low $\mathrm{pH}$ causes less growing of the plant and even death. So it is very interesting to find peroxidases in these two species that might be involved in this kind of stress. Additionally, this stress can be related to other stresses, like nutrient starvation or drought [112]. The C2 cluster is build by two PM peroxidases that are involved in plant development. AtPrx18 is related to the development of the floral organ and OsPrx5556 could be involved in the response to hormones and heat. 


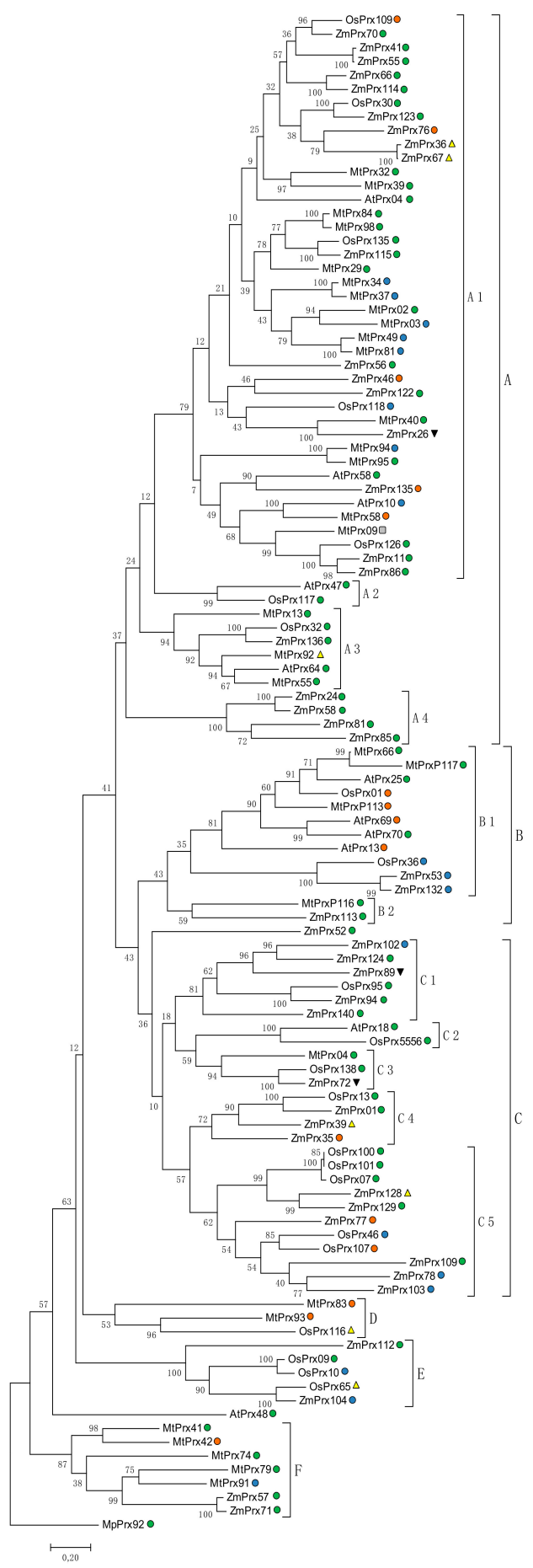

Figure 4. Phylogenetic analysis of peroxidases from Table 1 and MpPrx92 by the maximum likelihood method. The evolutionary history was inferred by using the maximum likelihood method based on the Jones, Taylor, Thornton (JTT) matrix-based model [110]. The tree with the highest log likelihood $(-58984.24)$ is shown. The percentage of trees in which the associated taxa clustered together is shown next to the branches. Initial tree(s) for the heuristic search were obtained automatically by applying Neighbor-Join and BioNJ algorithms to a matrix of pairwise distances estimated using a JTT model, and then selecting the topology with superior log likelihood value. The tree is drawn to scale, with branch lengths measured in the number of substitutions per site. The analysis involved 110 amino acid sequences. There were a total of 841 positions in the final dataset. Evolutionary analyses were conducted by Molecular Evolutionary Genetics Analysis (MEGA7) [111]. •, ER; •, PM; •, Vac; — Golgi; $\triangle$, MoM; $\mathbf{v}$, MiM. 
Peroxidases from group $\mathrm{C} 3$ seem to be involved in nitrogen starvation response. Three peroxidases of three different species, MtPrx04, OsPrx138 and ZmPrx72, build this cluster and, despite the fact that only one of these peroxidases was studied (MtPrx04), the similarity between them is so high that they may have the same function. This could mean that these peroxidases have a common origin to protect the plant against nutrient deficiency. Cluster $\mathrm{C} 4$ is build by peroxidases that are involved in processes like cell wall modification (e.g., ZmPrx01). Finally, group $\mathrm{C} 5$ contains peroxidases that are not characterized. A BLAST search suggested a function in response to different abiotic stresses like $\mathrm{pH}$ and drought (ZmPrx78) or nitrogen and phosphate starvation (OsPrx46 and OsPrx107).

Group D is formed by three peroxidases from barrel medic and rice that are not characterized.

Group E include mainly peroxidases that are involved in etiolation and are regulated by light and dark (e.g., ZmPrx104 and ZmPrx112). However, these functions are only theoretical because none of these peroxidases were characterized experimentally.

Finally, group F is involved mainly in nodulation (e.g., MtPrx41, MtPrx42 and MtPrx74). In accordance with this specialization of legumes, the majority of peroxidases were from barrel medic. Two peroxidases were from maize (ZmPrx57 and ZmPrx71), and these were separated from the others. The genes showed distinct expression patterns: zmprx 57 has been found in immature leaf, whereas zmprx 71 has been expressed in primary root [113]. Both proteins have a prediction for PM localization. At least one of them may respond in defense against pathogens. This function can be easily related to the nodulation in barrel medic plants. However, biochemical characterization of the maize peroxidases is still missing.

\section{Conclusions}

Molecular biodiversity of membrane-bound class III peroxidases appears to be higher then expected. Although plants evolved the same molecular mechanisms, true orthologues of membrane-bound peroxidases were not identified in the four species investigated. Besides soluble class III peroxidases that interact with the membrane by protein-protein interaction, type I membrane proteins may exist. Membrane-bound peroxidases are multifunctional enzymes that fulfill essential functions in plant development and stress response. Microcompartmentation and co-localization of PM-bound peroxidases with ROS-producing and detoxifying enzymes may probably not only detoxify hydrogen peroxide directly at the site of origin, but could also protect specific functional regions of the $\mathrm{PM}$ and fulfill specific functions. Biochemical characterization of membrane-bound peroxidases is still fragmentary and will need further elucidation. Some of these peroxidases may have the potential for marker-assisted breeding.

Author Contributions: S.L. designed the concept and structure of the paper, she prepared Figures 1-3, Tables 1 and 3, and wrote the main text. T.M.-C. performed the docking analyzes and the phylogenetic tree, prepared Figure 4, Table 2 and wrote the interpretation of phylogenetics. S.L. and T.M.-C. discussed and corrected the manuscript.

Acknowledgments: Financial support was given to S.L. by a research grant from DFG (DFG Lu-668/4-4) and to T.M.C. by a post doctoral grant (ED481B 2016/221-0) from the Xunta de Galicia, Spain. Funds for covering the costs to publish in open access were not available.

Conflicts of Interest: The authors declare no conflict of interest.

\section{Abbreviations}

$\begin{array}{ll}\text { AGP } & \text { Arabinogalactan protein } \\ \text { ARE } & \text { Antioxidant-responsive elements } \\ \text { AtPrx47 } & \text { Arabidopsis thaliana peroxidase } 47 \\ \text { AtPrx64 } & \text { AtPer64, Arabidopsis thaliana peroxidase } 64 \\ \text { AVLB } & -3^{\prime}, 4^{\prime} \text {-anhydrovinblastine } \\ \text { BLAST } & \text { Basic local alignment search tool } \\ \text { BvPrx12 } & \text { Beta vulgaris peroxidase } 12 \\ \text { CASPs } & \text { Casparian strip domain proteins }\end{array}$




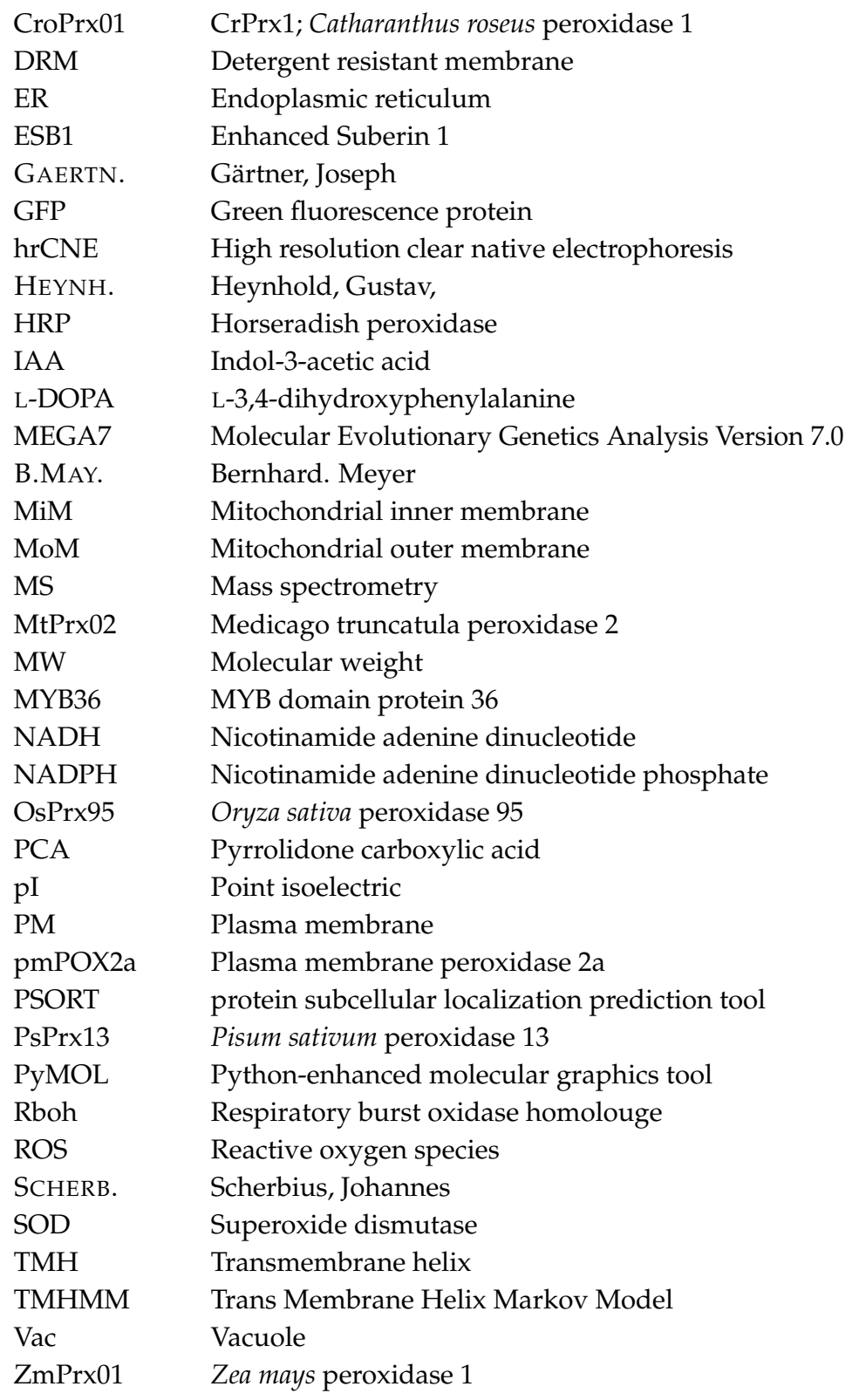

\section{References}

1. Welinder, K.G. Superfamily of plant, fungal and bacterial peroxidases. Curr. Opin. Struct. Biol. 1992, 2, 388-393. [CrossRef]

2. Zámocký, M.; Hofbauer, S.; Schaffner, I.; Gasselhuber, B.; Nicolussi, A.; Soudi, M.; Pirker, K.F.; Furtmüller, P.G.; Obinger, C. Independent evolution of four heme peroxidase superfamilies. Arch. Biochem. Biophys. 2015, 574, 108-119. [CrossRef] [PubMed]

3. Fawal, N.; Li, Q.; Savelli, B.; Brette, M.; Passaia, G.; Fabre, M.; Mathé, C.; Dunand, C. PeroxiBase: A database for large-scale evolutionary analysis of peroxidases. Nucleic Acids Res. 2013, 41, D441-D444. [CrossRef] [PubMed]

4. Duroux, L.; Welinder, K.G. The peroxidase gene family in plants: A phylogenetic overview. J. Mol. Evol. 2003, 57, 397-407. [CrossRef] [PubMed]

5. Tognolli, M.; Penel, C.; Greppin, H.; Simon, P. Analysis and expression of the class III peroxidase large gene family in Arabidopsis thaliana. Gene 2002, 288, 129-138. [CrossRef]

6. Welinder, K.G.; Justesen, A.F.; Kjaersgard, I.V.; Jensen, R.B.; Rasmussen, S.K.; Jespersen, H.M.; Duroux, L. Structural diversity and transcription of class III peroxidases from Arabidopsis thaliana. Eur. J. Biochem. 2002, 269, 6063-6081. [CrossRef] [PubMed] 
7. Passardi, F.; Cosio, C.; Penel, C.; Dunand, C. Peroxidases have more functions than a swiss army knife. Plant Cell Rep. 2005, 24, 255-265. [CrossRef] [PubMed]

8. Shigeto, J.; Tsutsumi, Y. Diverse functions and reactions of class III peroxidases. New Phytol. 2016, 209, 1395-1402. [CrossRef] [PubMed]

9. Pandey, V.P.; Awasthi, M.; Singh, S.; Tiwari, S.; Dwivedi, U.N. A comprehensive review on function and application of plant peroxidases. Biochem. Anal. Biochem. 2017, 6. [CrossRef]

10. Díaz, J.; Pomar, F.; Bernal, Á.; Merino, F. Peroxidases and the metabolism of capsaicin in Capsicum annuum L. Phytochem. Rev. 2004, 3, 141-157. [CrossRef]

11. Hiraga, S.; Sasaki, K.; Ito, H.; Ohashi, Y.; Matsui, H. A large family of class III plant peroxidases. Plant Cell Physiol. 2001, 42, 462-468. [CrossRef] [PubMed]

12. Wang, Y.; Wang, Q.; Zhao, Y.; Han, G.; Zhu, S. Systematic analysis of maize class III peroxidase gene family reveals a conserved subfamily involved in abiotic stress response. Gene 2015, 566, 95-108. [CrossRef] [PubMed]

13. De Gara, L. Class III peroxidases and ascorbate metabolism in plants. Phytochem. Rev. 2004, 3, $195-205$. [CrossRef]

14. Lüthje, S.; Meisrimler, C.N.; Hopff, D.; Möller, B. Phylogeny, topology, structure and functions of membrane-bound class III peroxidases in vascular plants. Phytochemistry 2011, 72, 1124-1135. [CrossRef] [PubMed]

15. Narendra, S.; Venkataramani, S.; Shen, G.; Wang, J.; Pasapula, V.; Lin, Y.; Kornyeyev, D.; Holaday, A.S.; Zhang, $\mathrm{H}$. The arabidopsis ascorbate peroxidase 3 is a peroxisomal membrane-bound antioxidant enzyme and is dispensable for arabidopsis growth and development. J. Exp. Bot. 2006, 57, 3033-3042. [CrossRef] [PubMed]

16. Laloue, H.; Weber-Lofti, F.; Lucau-Danila, A.; Guillemaut, P. Identification of ascorbate and guaiacol peroxidase in needle chloroplasts of spruce trees. Plant Physiol. Biochem. 1997, 35, 341-346.

17. Ros Barceló, A.; Ferrer, M.A.; Florenciano, G.E.; Muñoz, R. The tonoplast localization of two basic isoperoxidases of high $\mathrm{pI}$ in Lupinus. Bot. Acta 1991, 104, 272-278. [CrossRef]

18. Andrews, J.; Adams, S.R.; Burton, K.S.; Evered, C.E. Subcellular localization of peroxidase in tomato fruit skin and possible implications for the regulation of fruit growth. J. Exp. Bot. 2002, 53, 2185-2191. [CrossRef] [PubMed]

19. Andrews, J.; Adams, S.R.; Burton, K.S.; Edmondson, R.N. Partial purification of tomato fruit peroxidase and its effect on the mechanical properties of tomato fruit skin. J. Exp. Bot. 2002, 53, 2393-2399. [CrossRef] [PubMed]

20. Fernandez-Calvino, L.; Faulkner, C.; Walshaw, J.; Saalbach, G.; Bayer, E.; Benitez-Alfonso, Y.; Maule, A. Arabidopsis plasmodesmal proteome. PLoS ONE 2011, 6, e18880. [CrossRef] [PubMed]

21. Costa, M.M.R.; Hilliou, F.; Duarte, P.; Pereira, L.G.; Almeida, I.; Leech, M.; Memelink, J.; Barcelo, A.R.; Sottomayor, M. Molecular cloning and characterization of a vacuolar class III peroxidases involved in the metabolism of anticancer alkaloids in Catharanthus roseus. Plant Physiol. 2008, 146, 403-417. [CrossRef] [PubMed]

22. Mika, A.; Buck, F.; Lüthje, S. Membrane-bound class III peroxidases: Identification, biochemical properties and sequence analysis of isoenzymes purified from maize (Zea mays L.) roots. J. Proteom. 2008, 71, 412-424. [CrossRef] [PubMed]

23. Sottomayor, M.; Ros Barceló, A. Peroxidase from Catharanthus roseus (L.) G. Don and the biosynthesis of a-30-40-anhydrovinlastine: A specific role for a multifunctional enzyme. Protoplasma 2003, 222, 97-105. [CrossRef] [PubMed]

24. Mika, A.; Lüthje, S. Properties of guaiacol peroxidase activities isolated from corn root plasma membranes. Plant Physiol. 2003, 132, 1489-1498. [CrossRef] [PubMed]

25. Lüthje, S.; Möller, B.; Perrineau, F.C.; Wöltje, K. Plasma membrane electron pathways and oxidative stress. Antioxid. Redox Signal. 2013, 18, 2163-2183. [CrossRef] [PubMed]

26. Cheng, Y.; Qi, Y.; Zhu, Q.; Chen, X.; Wang, N.; Zhao Chen, H.; Cui, X.; Xu, L.; Zhang, W. New changes in the plasma-membrane-associated proteome of rice roots under salt stress. Proteomics 2009, 9, 3100-3114. [CrossRef] [PubMed]

27. Meisrimler, C.N.; Planchon, S.; Renaut, J.; Sergeant, K.; Lüthje, S. Alteration of plasma membrane-bound redox systems of iron deficient pea roots by chitosan. J. Proteom. 2011, 74, 1437-1449. [CrossRef] [PubMed] 
28. Lee, Y.; Rubio, M.C.; Alassimone, J.; Geldner, N. A mechanism for localized lignin deposition in the endodermis. Cell 2013, 153, 402-412. [CrossRef] [PubMed]

29. Kamiya, T.; Borghi, M.; Wang, P.; Danku, J.M.; Kalmbach, L.; Hosmani, P.S.; Naseer, S.; Fujiwara, T.; Geldner, N.; Salt, D.E. The MYB36 transcription factor orchestrates Casparian strip formation. Proc. Natl. Acad. Sci. USA 2015, 112, 10533-10538. [CrossRef] [PubMed]

30. Tokunaga, N.; Kaneta, T.; Sato, S.; Sato, Y. Analysis of expression profiles of three peroxidase genes associated with lignification in Arabidopsis thaliana. Physiol. Plantarum 2009, 136, 237-249. [CrossRef] [PubMed]

31. Zhu, T.; Budworth, P.; Han, B.; Brown, D.; Chang, H.S.; Zou, G.; Wang, X. Toward elucidating the global gene expression patterns of developing Arabidopsis: Parallel analysis of 8300 genes by a high-density oligonucleotide probe array. Plant Physiol. Biochem. 2001, 39, 221-242. [CrossRef]

32. Wu, Y.; Yang, Z.; How, J.; Xu, H.; Chen, L.; Li, K. Overexpression of a peroxidase gene (AtPrx64) of Arabidopsis thaliana in tobacco improves plant's tolerance to aluminum stress. Plant Mol. Biol. 2017, 95, 157-168. [CrossRef] [PubMed]

33. Lefebvre, B.; Furt, F.; Hartmann, M.A.; Michaelson, L.V.; Carde, J.P.; Sargueil-Boiron, F.; Rossignol, M.; Napier, J.A.; Cullimore, J.; Bessoule, J.J.; et al. Characterization of lipid rafts from Medicago truncatula root plasma membranes: A proteomic study reveals the presence of a raft-associated redox system. Plant Physiol. 2007, 144, 408-418. [CrossRef] [PubMed]

34. Gutierrez-Carbonell, E.; Takahashi, D.; Lüthje, S.; González-Reyes, J.A.; Mongrand, S.; Contreras-Moreira, B.; Abadía, A.; Uemura, M.; Abadía, J.; López-Millán, A.F. A shotgun proteomic approach reveals that Fe deficiency causes marked changes in the protein profiles of plasma membrane and detergent-resistant microdomain preparations from Beta vulgaris roots. J. Proteome Res. 2016, 15, 2510-2524. [CrossRef] [PubMed]

35. Sottomayor, M.; Duarte, P.; Figueiredo, R.; Ros Barceló, A. A vacuolar class III peroxidase and the metabolism of anticancer indole alkaloids in Catharanthus roseus. Plant Signal. Behav. 2008, 3, 899-901. [CrossRef] [PubMed]

36. Berglund, G.I.; Carlsson, G.H.; Smith, A.T.; Szöke, H.; Henriksen, A.; Hajdu, J. The catalytic pathway of horseradish peroxidase at high resolution. Nature 2003, 417, 463-468. [CrossRef] [PubMed]

37. Poulos, T.L.; Edwards, S.L.; Wariishi, H.; Gold, M.H. Crystallographic refinement of lignin peroxidase at 2 A. J. Biol. Chem. 1993, 268, 4429-4440. [PubMed]

38. Newmyer, S.L.; Ortiz de Montellano, P.R. Horseradish peroxidase His-42->Ala, His-42->Val, and Phe-41->Ala mutants. Histidine catalysis and control of substrate access to the heme iron. J. Biol. Chem. 1995, 270, 19430-19438. [CrossRef] [PubMed]

39. Finkelstein, I.J.; Ishikaea, H.; Kim, S.; Massari, A.M.; Fayer, M.D. Substrate binding and protein conformational dynamics measured by 2D-IR vibrational echo spectroscopy. Proc. Natl. Acad. Sci. USA 2007, 104, 2637-2642. [CrossRef] [PubMed]

40. Sievers, F.; Wilm, A.; Dineen, D.; Gibson, T.J.; Karplus, K.; Li, W.; Lopez, R.; McWilliam, H.; Remmert, M.; Söding, J.; et al. Fast, scalable generation of high-quality protein multiple sequence alignments using Clustal Omega. Mol. Syst. Biol. 2011, 7. [CrossRef] [PubMed]

41. Watanabe, L.; de Moura, P.R.; Bleicher, L.; Nascimento, A.S.; Zamorano, L.S.; Calvete, J.J.; Sanz, L.; Perez, A.; Bursakov, S.; Roig, M.G.; et al. Crystal structure of highly glycosylated peroxidase from Royal Palm Tree. J. Struct. Biol. 2010, 169, 226-242. [CrossRef] [PubMed]

42. Moural, T.W.; Lewis, K.M.; Barnaba, C.; Zhu, F.; Palmer, N.A.; Sarath, G.; Scully, E.D.; Jones, J.P.; Sattler, S.E.; Kang, C. Characterization of Class III Pperoxidases from switchgrass. Plant Physiol. 2017, 173, 417-433. [CrossRef] [PubMed]

43. Nnamchi, C.I.; Parkin, G.; Efimov, I.; Basran, J.; Kwon, H.; Svistunenko, D.A.; Agirre, J.; Okolo, B.N.; Moneke, A.; Nwanguma, B.C.; et al. Structural and spectroscopic characterisation of a heme peroxidase from Sorghum. J. Biol. Inorg. Chem. 2016, 21, 63-70. [CrossRef] [PubMed]

44. Krogh, A.; Larsson, B.; von Heijne, G.; Sonnhammer, E.L.L. Predicting transmembrane protein topology with a hidden Markov model: Application to complete genomes. J. Mol. Biol. 2001, 305, 567-580. [CrossRef] [PubMed]

45. Nielsen, H.; Krogh, A. Prediction of signal peptides and signal anchors by a hidden Markov model. Proc. Int. Conf. Intell. Syst. Mol. Biol. 1998, 6, 122-130. [PubMed] 
46. Blom, N.; Sicheritz-Ponten, T.; Gupta, R.; Gammeltoft, S.; Brunak, S. Prediction of post-translational glycosylation and phosphorylation of proteins from the amino acid sequence. Proteomics 2004, 4, 1633-1649. [CrossRef] [PubMed]

47. Nakai, K.; Kanehisa, M. A knowledge base for predicting protein localization sites in eukaryotic cells. Genomics 1992, 14, 897-911. [CrossRef]

48. Newman, T.; De Bruijn, F.J.; Green, P.; Keegstra, K.; Kende, H.; McIntosh, L.; Ohlrogge, J.; Raikhel, N.; Somerville, S.; Thomashow, M. Genes galore: A summary of methods for accessing results from large-scale partial sequencing of anonymous Arabidopsis cDNA clones. Plant Physiol. 1994, 106, 1241-1255. [CrossRef] [PubMed]

49. Kelley, L.A.; Mezulis, S.; Yates, C.M.; Stemberg, M. The Phyre2 web portal for protein modeling, prediction and analysis. Nat. Protoc. 2015, 10, 845-858. [CrossRef] [PubMed]

50. Wass, M.N.; Kelley, L.A.; Sternberg, M.J. 3DLigandSite: Predicting ligand-binding sites using similar structures. NAR 2010, 38, 469-473. [CrossRef] [PubMed]

51. Lüthje, S.; Meisrimler, C.N.; Hopff, D.; Schütze, T.; Köppe, J.; Heino, K. Class III peroxidases. Meth. Mol. Biol. 2014, 1072, 687-706. [CrossRef]

52. Asada, K.; Miyake, C.; Ogawa, K.; Hossain, M.A. Microcompartmentation of ascorbate peroxidase and regeneration of ascorbate from ascorbate radical: Its dual role in chloroplasts. In Proceedings of the IV. International Symposium on Plant Peroxidases: Biochemistry and Physiology, Vienna, Austria, 6-10 July 1996; Obinger, C., Burner, U., Ebermann, R., Penel, C., Greppin, H., Eds.; pp. 163-167, ISBN 2881640087.

53. Jespersen, H.M.; Kjærsgard, V.H.; Østergaard, L.; Welinder, K.G. From sequence analysis of three novel ascorbate peroxidases from Arabidopsis thaliana to structure, function and evolution of seven types of ascorbate peroxidase. Biochem. J. 1997, 326, 305-310. [CrossRef] [PubMed]

54. Kieselbach, T.; Bystedt, M.; Hynds, P.; Robinson, C.; Schroder, W.P. A peroxidase homologue and novel plastocyanin located by proteomics to the Arabidopsis chloroplast thylakoid lumen. FEBS Lett. 2000, 480, 271-276. [CrossRef]

55. Yabuta, Y.; Motoki, T.; Yoshimura, K.; Takeda, T.; Ishikawa, T.; Shigeoka, S. Thylakoid membrane-bound ascorbate peroxidase is a limiting factor of antioxidative systems under photo-oxidative stress. Plant J. 2002, 32, 915-925. [CrossRef] [PubMed]

56. Bunkelmann, J.; Trelease, R.N. Ascorbate peroxidase. A prominent membrane protein in oilseed glyoxysomes. Plant Physiol. 1996, 110, 589-598. [CrossRef] [PubMed]

57. Ishikawa, T.; Yoshimura, K.; Sakai, K.; Tamoi, M.; Takeda, T.; Shigeoka, S. Molecular characterization and physiological role of a glyoxysome-bound ascorbate peroxidase from spinach. Plant Cell Physiol. 1998, 39, 23-34. [CrossRef] [PubMed]

58. Nito, K.; Yamaguchi, K.; Kondo, M.; Hayashi, M.; Nishimura, M. Pumpkin peroxisomal ascorbate peroxidase is localized on peroxisomal membranes and unknown membranous structures. Plant Cell Physiol. 2001, 42, 20-27. [CrossRef] [PubMed]

59. Yamaguchi, K.; Mori, H.; Nishimura, M. A novel isoenzyme of ascorbate peroxidase localized on glyoxysomal and leaf peroxisomal membranes in pumpkin. Plant Cell Physiol. 1995, 36, 1157-1162. [CrossRef] [PubMed]

60. Lüthje, S.; Hopff, D.; Schmitt, A.; Meisrimler, C.N.; Menckhoff, L. Hunting for low abundant redox proteins in plant plasma membranes. J. Proteom. 2009, 72, 475-483. [CrossRef] [PubMed]

61. Welinder, K.G.; Larsen, Y.B. Covalent structure of soybean seed coat peroxidase. Biochim. Biophys. Acta 2004, 1698, 121-126. [CrossRef] [PubMed]

62. Sigrist, C.J.A.; de Castro, E.; Cerutti, L.; Cuche, B.A.; Hulo, N.; Bridge, A.; Bougueleret, L.; Xenarios. New and continuing developments at PROSITE. Nucleic Acids Res. 2012, 21, D344-D347. [CrossRef]

63. Mika, A.; Boenisch, M.J.; Hopff, D.; Lüthje, S. Membrane-bound guaiacol peroxidases are regulated by methyl jasmonate, salicylic acid, and pathogen elicitors. J. Exp. Bot. 2010, 61, 831-841. [CrossRef] [PubMed]

64. Mika, A.; (University of Hamburg, Hamburg, Germany); Lüthje, S.; (University of Hamburg, Hamburg, Germany). Personal communication, 2007.

65. Morel, J.; Claverol, S.; Mongrand, S.; Furt, F.; Fromentin, J.; Bessoule, J.J.; Blein, J.P.; Simon-Plas, F. Proteomics of plant detergent-resistant membranes. Mol. Cell. Proteom. 2006, 5, 1396-1411. [CrossRef] [PubMed]

66. Simon-Plas, F.; Perraki, A.; Bayer, E.; Gerbeau-Pissot, P.; Mongrand, S. An update on plant membrane rafts. Curr. Opin. Plant Biol. 2011, 14, 642-649. [CrossRef] [PubMed] 
67. Showalter, A.M. Arabinogalactan-proteins: Structure, expression and function. Cell Mol. Life Sci. 2001, 58, 1399-1417. [CrossRef] [PubMed]

68. Wink, M. The plant vacuole: A multifunctional compartment. J. Exp. Bot. 1993, 44, 231-246.

69. Carqueijeiro, I.; Noronha, H.; Duarte, P.; Gerós, H.; Sottomayor, M. Vacuolar transport of the medicinal alkaloids from Catharanthus roseus is mediated by a proton-driven antiport. Plant Physiol. 2013, 162, 1486-1496. [CrossRef] [PubMed]

70. Lüthje, S. Plasma membrane redox systems: Lipid rafts and protein assemblies. Prog. Bot. 2008, 69, 169-200. [CrossRef]

71. Roppolo, D.; De Rybel, B.; Tendon, V.D.; Pfister, A.; Alassimone, J.; Vermeer, J.E.; Yamazaki, M.; Stierhof, Y.D.; Beeckman, T.; Geldner, N. A novel protein family mediates Casparian strip formation in the endodermis. Nature 2011, 473, 380-383. [CrossRef] [PubMed]

72. Halpin, C. Cell Biology: Up Against the Wall. Curr. Biol. 2013, 23, R1050. [CrossRef] [PubMed]

73. Christensen, J.H.; Bauw, G.; van Montagu, M.; Boerjan, W. Towards the identification of lignin specific peroxidases in poplar. In Proceedings of the IV. International Symposium on Plant Peroxidases: Biochemistry and Physiology, Vienna, Austria, 6-10 July 1996; Obinger, C., Burner, U., Ebermann, R., Penel, C., Greppin, H., Eds.; pp. 113-117, ISBN 2881640087.

74. Cosio, C.; Dunand, C. Specific functions of individual class III peroxidase genes. J. Exp. Bot. 2009, 60, 391-409. [CrossRef] [PubMed]

75. Mika, A.; Minibayeva, F.; Beckett, R.; Lüthje, S. Possible functions of extracellular peroxidases in stress-induced generation and detoxification of active oxygen species. Phytochem. Rev. 2004, 3, 173-193. [CrossRef]

76. Sies, H. Hydrogen peroxide as a central redox signaling molecule in physiological oxidative stress: Oxidative eustress. Redox Biol. 2017, 11, 613-619. [CrossRef] [PubMed]

77. Noctor, G.; Reichheld, J.P.; Foyer, C.H. ROS-related redox regulation and signaling in plants. Semin. Cell. Dev. Biol. 2018, 80, 3-12. [CrossRef] [PubMed]

78. Schraudner, M.; Langebartels, C.; Sandermann, H., Jr. Plant defence systems and ozone. Biochem. Soc. Trans. 1996, 24, 456-461. [CrossRef] [PubMed]

79. Bolwell, G.P.; Bindschedler, L.V.; Blee, K.A.; Butt, V.S.; Davies, D.R.; Gardner, S.L.; Gerrish, C.; Minbayeva, F. The apoplastic oxidative burst in response to biotic stress in plants: A three-component system. J. Exp. Bot. 1996, 53, 1367-1376. [CrossRef]

80. Schützendübel, A.; Polle, A. Plant responses to abiotic stresses: Heavy metal-induced oxidative stress and protection by mycorrhization. J. Exp. Bot. 2002, 53, 1351-1365. [CrossRef] [PubMed]

81. Minibayeva, F.; Lüthje, S.; Kolesnikov, O.; Chasov, A.; Beckett, R.P.; Vylegzhanina, N.; Buck, F.; Böttger, M. Wound-induced apoplastic peroxidase activities: Their roles in the production and detoxification of reactive oxygen species. Plant Cell Environ. 2009, 32, 497-508. [CrossRef] [PubMed]

82. Cakmak, I.; van de Wetering, D.A.M.; Marschner, H.; Bienfait, H.F. Involvement of superoxide radical in extracellular ferric reduction by iron-deficient bean roots. Plant Physiol. 1987, 85, 310-314. [CrossRef] [PubMed]

83. Qiu, Q.S.; Liang, H.G. Lipid peroxidation caused by the redox system of plasma membranes from wheat roots. J. Plant Physiol. 1995, 145, 261-265. [CrossRef]

84. Rawyler, A.; Arpagaus, S.; Braendle, R. Impact of oxygen stress and energy availability on membrane stability of plant cells. Ann. Bot. 2002, 90, 499-507. [CrossRef] [PubMed]

85. Marjamaa, K.; Kukkola, E.M.; Fagerstedt, K. The role of xylem class III peroxidases in lignification. J. Exp. Bot. 2009, 60, 367-376. [CrossRef] [PubMed]

86. Vanholme, R.; Demedts, B.; Morreel, K.; Ralph, J.; Boerjan, W. Lignin biosynthesis and structure. Plant Physiol. 2010, 153, 895-905. [CrossRef] [PubMed]

87. Boerjan, W.; Ralph, J.; Baucher, M. Lignin biosynthesis. Ann. Rev. Plant Biol. 2003, 54, 519-546. [CrossRef] [PubMed]

88. Novo-Uzal, E.; Fernández-Pérez, F.; Herrero, J.; Gutiérrez, J.; Gómez-Ros, L.V.; Bernal, M.Á.; Díaz, J.; Cuello, J.; Pomar, F.; Pedreño, M.A. From Zinnia to Arabidopsis: Approaching the involvement of peroxidases in lignification. J. Exp. Bot. 2013, 64, 3499-3518. [CrossRef] [PubMed]

89. Vishwanath, S.J.; Delude, C.; Domergue, F.; Rowland, O. Suberin: Biosynthesis, regulation, and polymer assembly of a protective extracellular barrier. Plant Cell Rep. 2015, 34, 573-586. [CrossRef] [PubMed] 
90. Takahama, U. Hydrogen peroxide scavenging systems in vacuoles of mesophyll cells of Vicia faba. Phytochemistry 1992, 31, 1127-1133. [CrossRef]

91. Soares, A.R.; Marchiosi, R.; Siqueira-Soares Rde, C.; Barbosa de Lima, R.; Dantas dos Santos, W.; Ferrarese-Filho, O. The role of L-DOPA in plants. Plant Signal. Behav. 2014, 9, e28275. [CrossRef] [PubMed]

92. Kawano, T. Roles of the reactive oxygen species-generating peroxidase reactions in plant defense and growth induction. Plant Cell Rep. 2003, 21, 829-837. [CrossRef] [PubMed]

93. Ranocha, P.; Dima, O.; Nagy, R.; Felten, J.; Corratgé-Faillie, C.; Novák, O.; Morreel, K.; Lacombe, B.; Martinez, Y.; Pfrunder, S.; et al. Arabidopsis WAT1 is a vacuolar auxin transport facilitator required for auxin homoeostasis. Nat. Commun. 2013, 4, 2625. [CrossRef] [PubMed]

94. Journet, E.P. MtPrx02, Unpublished, PeroxiBase.

95. Takahama, U.; Oniki, T. Effects of ascorbate on oxidation of hydroxycinnamic acid derivatives and the mechanism of oxidation of sinapic acid by cell wall-bound peroxidases. Plant Cell Phys. 1994, 35, 593-600. [CrossRef]

96. Pomar, F.; Merino, F.; Ros Barceló, A. O-4-linked coniferyl and sinapyl aldehyde in lignifying cell walls are the main targets of the Wiesner (phloroglucinol-HCl) reaction. Protoplasma 2002, 220, 17-28. [CrossRef] [PubMed]

97. Lamb, C.; Dixon, R.A. The oxidative burst in plant disease resistance. Annu. Rev. Plant Physiol. Plant Mol. Biol. 1997, 48, 251-275. [CrossRef] [PubMed]

98. Liu, T.T.; Wu, P.; Wang, H.; Zhou, Q. Response of soybean seed germination to cadmium and acid rain. Biol. Trace Elem. Res. 2011, 144, 1186-1196. [CrossRef] [PubMed]

99. Steffens, B. The role of ethylene and ROS in salinity, heavy metal, and flooding responses in rice. Front. Plant Sci. 2014, 5, 685. [CrossRef] [PubMed]

100. Zhang, H.; Liu, X.L.; Zhang, R.X.; Yuan, H.Y.; Wang, M.M.; Yang, H.Y.; Ma, H.Y.; Liu, D.; Jiang, C.J.; Liang, Z.W. Root damage under alkaline stress is associated with reactive oxygen species accumulation in rice (Oryza sativa L.). Front. Plant Sci. 2017, 8, 1580. [CrossRef] [PubMed]

101. Sergio, L.; Cardinali, A.; De Paola, A.; Di Venere, D. Biochemical properties of soluble and bound peroxidases from artichoke heads and leaves. Food Technol. Biotechnol. 2009, 47, 32-38.

102. Martínez-Cortés, T.; Pomar, F.; Espiñeira, J.M.; Merino, F.; Novo-Uzal, E. Purification and kinetic characterization of two peroxidases of Selaginella martensii Spring. involved in lignification. Plant Physiol. Biochem. 2012, 52, 130-139. [CrossRef] [PubMed]

103. Zhang, Y.K.; Zhu, D.F.; Zhang, Y.P.; Chen, H.Z.; Xiang, J.; Lin, X.Q. Low pH-Induced changes of antioxidant enzyme and ATPase activities in the roots of rice (Oryza sativa L.) seedlings. PLoS ONE 2015, 10, e0116971. [CrossRef] [PubMed]

104. Haslekås, C.; Grini, P.E.; Nordgard, S.H.; Thorstensen, T.; Viken, M.K.; Nygaard, V. ABI3 mediates expression of the peroxiredoxin antioxidant AtPER1 gene and induction by oxidative stress. Plant Mol. Biol. 2003, 53, 313-326. [CrossRef] [PubMed]

105. Ferreres, F.; Figueiredo, R.; Bettencourt, S.; Carqueijeiro, I.; Oliveira, J.; Gil-Izquierdo, A.; Pereira, D.M.; Valentao, P.; Andrade, P.B.; Duarte, P.; et al. Identification of phenolic compounds in isolated vacuoles of the medicinal plant Catharanthus roseus and their interaction with vacuolar class III peroxidase: $\mathrm{An}_{2} \mathrm{H}_{2}$ affair? J. Exp. Bot. 2011, 62, 2841-2854. [CrossRef] [PubMed]

106. Kumar, S.; Jaggi, M.; Taneja, J.; Sinha, A.K. Cloning and characterization of two new Class III peroxidase genes from Catharanthus roseus. Plant Physiol. Biochem. 2011, 49, 404-412. [CrossRef] [PubMed]

107. Baum, S.F.; Tran, P.N.; Silk, W.K. Effects of salinity on xylem structure and water use in growing leaves of sorghum. New Phytol. 2000, 146, 119-127. [CrossRef]

108. Karahara, I.; Ikeda, A.; Kodo, T.; Uetake, Y. Development of the Casparian strip in primary roots of maize under salt stress. Planta 2004, 219, 41-47. [CrossRef] [PubMed]

109. Downie, J.A. Legume nodulation. Curr. Biol. 2014, 24, 184-190. [CrossRef] [PubMed]

110. Jones, D.T.; Taylor, W.R.; Thornton, J.M. The rapid generation of mutation data matrices from protein sequences. Comput. Appl. Biosci. 1992, 8, 275-282. [CrossRef] [PubMed]

111. Kumar, S.; Stecher, G.; Tamura, K. MEGA7: Molecular evolutionary genetics analysis version 7.0 for bigger datasets. Mol. Biol. Evol. 2016, 33, 1870-1874. [CrossRef] [PubMed] 
112. Ngoune Tandzi, L.; Shelton Mutengwa, C.; Mangaptche Ngonkeu, E.L.; Gracen, V. Breeding maize for tolerance to acidic soils: A review. Agronomy 2018, 8, 84. [CrossRef]

113. Sekhon, R.S.; Lin, H.; Childs, K.L.; Hansey, C.N.; Buell, C.R.; de Leon, N.; Kaeppler, S.M. Genome-wide atlas of transcription during maize development. Plant J. 2011, 66, 553-563. [CrossRef] [PubMed] 